Rhode Island College

Digital Commons @ RIC

April 2021

\title{
Does Oral Chlorhexidine Mouth Care Prior to Intubation Impact Ventilator-Associated Pneumonia? A Systematic Review
}

Hannah Rothhaar

Follow this and additional works at: https://digitalcommons.ric.edu/etd

Part of the Nursing Commons

\section{Recommended Citation}

Rothhaar, Hannah, "Does Oral Chlorhexidine Mouth Care Prior to Intubation Impact Ventilator-Associated Pneumonia? A Systematic Review" (2021). Master's Theses, Dissertations, Graduate Research and Major Papers Overview. 387.

https://digitalcommons.ric.edu/etd/387

This Major Paper is brought to you for free and open access by the Master's Theses, Dissertations, Graduate Research and Major Papers at Digital Commons @ RIC. It has been accepted for inclusion in Master's Theses, Dissertations, Graduate Research and Major Papers Overview by an authorized administrator of Digital Commons @ RIC. For more information, please contact digitalcommons@ric.edu. 


\section{DOES ORAL CHLORHEXIDINE MOUTH CARE PRIOR \\ TO INTUBATION IMPACT \\ VENTILATOR-ASSOCIATED PNEUMONIA?}

\section{A SYSTEMATIC REVIEW}

by

Hannah Rothhaar

A Major Paper Submitted in Partial Fulfillment

of the Requirements for the Degree of

Master of Science in Nursing

in

The School of Nursing

Rhode Island College

2021 


\begin{abstract}
Background: Chlorhexidine gluconate $(\mathrm{CHG})$ is a broad-spectrum antiseptic agent that has become widely used for mouth care in intubated patients. Many studies have found it to be effective in the prevention of ventilator-associated pneumonia (VAP) when used after intubation; however, there is very limited research exploring the proper time to initiate CHG. Purpose: The purpose of this systematic review was to determine if the use of oral care with $\mathrm{CHG}$ prior to intubation impacts the incidence of VAP. Methods: The Preferred Reporting Items for Systematic reviews and Meta-Analyses (PRISMA) was used to guide the selection process of articles and the Critical Appraisal Skills Programme (CASP) was used to critically appraise the randomized control trials (RCTs) selected for this systematic review. Four randomized RCTs met inclusion criteria. Results: Three of the four RCTs which met inclusion criteria, Houston et al. (2002), DeRiso et al. (1996), and Lin et al. (2015), showed an improvement in VAP rates with the use of preintubation CHG in cardiac surgery patients. Only one RCT, the Munro et al. (2015) study, showed no benefit; this was the only study that included non-cardiac surgery patients. Conclusion: Based on the results of this systematic review, it can only be recommended that cardiac surgery patients receive CHG prior to or after intubation; however, more research needs to be done to determine the most effective dosing, frequency, and $\mathrm{CHG}$ application procedure. In addition, further study exploring the safety of administering CHG prior to intubation in noncardiac surgery patients is needed.
\end{abstract}




\section{Acknowledgements}

I would like to thank my family, especially my husband and mother for supporting me through this challenging journey. Without you, none of this would have been possible. Also, special thanks to Professor Joan Walsh for guiding me through this paper with grace. 


\section{Table of Contents}

Background/Statement of the Problem ......................................................... 1

Literature Review .................................................................................... 3

Theoretical Framework.............................................................................. 18

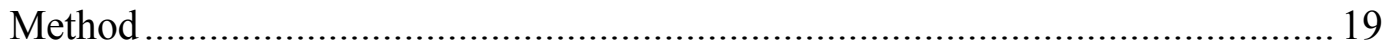

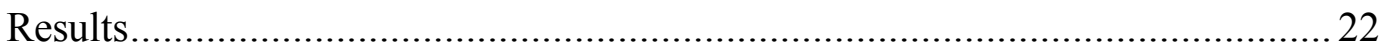

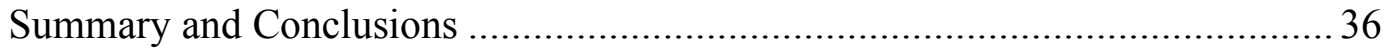

Recommendations and Implications for Advanced Nursing Practice.................. 37

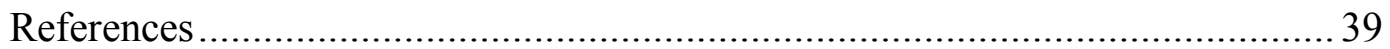

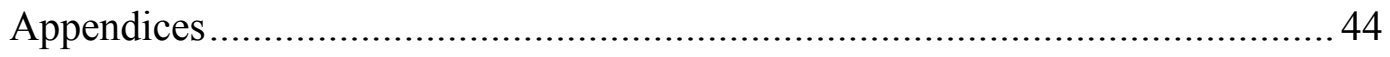


Does Oral Chlorhexidine Mouth Care Prior to Intubation Impact Ventilator-Associated Pneumonia?

A Systematic Review

\section{Background/Statement of the Problem}

Hospital-acquired infections (HAIs) have a significant impact on mortality and health care costs. The five HAIs identified by the Centers for Disease Control and Prevention (CDC) include central line-associated bloodstream infections (CLABSI), catheter-associated urinary tract infection (CAUTI), surgical site infection (SSI), clostridium difficile-associated diarrhea (CDAD), and ventilator-associated pneumonia (VAP) (CDC, 2010). According to the National Nosocomial Infection Surveillance System VAP is the second most common nosocomial infection after urinary tract infections. Ventilator-associated pneumonia occurs in 9-27\% of all intubated patients (American Thoracic Society; Infectious Diseases Society of America, 2005) leading to prolonged intubation and hospitalizations. A diagnosis of VAP can have a huge impact on mortality with an estimated cost upwards of $\$ 40,000$ per patient and a mortality rate estimated between 27-76\% (Klompas, Speck, Howell, et al., 2014).

The Centers for Medicare and Medicaid Services listed VAP as one of the most reasonably preventable diseases. Sedwick et al. (2012) explain that since the centers view VAP as preventable, insurance companies may not reimburse hospitals for the diagnosis of VAP leading to a huge economic burden. With such a large mortality and financial burden, many hospitals utilize "VAP Bundles" which provide strategies to prevent the occurrence of VAP. Components of the VAP bundle may include: elevation of the head of the bed to $30^{\circ}$ to $45^{\circ}$; prophylaxis for peptic ulcer disease; prophylaxis for deep-vein 
thrombosis; daily interruption of sedation (sedation holiday); daily assessment of readiness for extubation; and daily oral care with chlorhexidine.

Chlorhexidine gluconate $(\mathrm{CHG})$ is a broad-spectrum antiseptic agent that has become widely used for mouth care in intubated patients. Many studies have found it to be effective in the prevention of VAP when used after intubation. There is very limited research exploring the proper time to initiate chlorhexidine. The purpose of this paper was to determine if the use of oral care with chlorhexidine prior to intubation impacts the incidence of ventilator-associated pneumonia. 


\section{Literature Review}

A literature search was performed using CINHAL, Google Scholar, Cochrane, and Medscape combining the key terms: ventilator-associated pneumonia; chlorhexidine; and oral care. The additional term prior to intubation was also included later in the literature search. Literature was searched from 2005 to 2020 . Searches were limited to the English language and articles that included adults 18 years and older.

\section{The Body's Natural Defense Mechanisms for Prevention of Respiratory Infection}

A healthy person has multiple host defense mechanisms that hinder the development of pneumonia. The major defense mechanisms include airway barriers such as the epiglottis, cough reflexes, mucus, and mucociliary clearance (Safder et al., 2005). Mucosal ciliary move bacteria up and out of the bronchioles and a cough reflex assists this process. Additionally, the cellular and humoral immune systems help to eradicate potential pathogens on a cellular and extracellular level, respectively. In the mechanically ventilated patients, however, multiple factors compromise the body's natural defenses such as critical illness, comorbidities, and malnutrition thereby impairing the immune system. Furthermore, endotracheal intubation blocks the cough reflex and mucociliary clearance, injures the tracheal epithelial surface, and provides a direct passage of bacteria into the lower respiratory tract (Safder et al., 2005).

\section{Pathophysiology of VAP}

Normally, the lower respiratory tract is sterile whereas pneumonia is an infection in the lungs that causes the air sacs, or alveoli, to fill up with fluid or pus. The major routes of VAP are from oropharyngeal colonization, from the stomach related to secondary colonization, or from endotracheal-tube (ETT) biofilms (Safder et al., 2005). A 
biofilm is a collection of microbes that form an extracellular matrix or "slime" that traps bacteria or fungus and can lead to an infection (Bonez et al., 2013). The mechanical process of intubation alone facilitates microbial entry into the lungs by disrupting the body's natural defense between the oropharynx and trachea allowing micro-aspiration. Critically ill patients may have a depressed level of consciousness further compounding the decreased gag reflex and pooling of secretions. Intubated patients are also at increased risk for the buildup of dental plaque and biofilms, which can harbor respiratory pathogens. This plaque accumulation may create an environment that allows for the adherence of organisms such as pseudomonas aeruginosa (Berry et al., 2011). The positive pressure from the ventilator then propels oral contaminants forward into the lungs.

\section{Diagnosis of VAP}

One of the significant challenges in diagnosing VAP is that there is no recognized diagnostic gold standard, leading to both under and over diagnosis. Many conditions in an intubated patient such as congestive heart failure or sepsis can mimic signs and symptoms of VAP as well as how they appear on imaging. As a result, this may interfere with correct and timely diagnosis (Kollef, 2018).

Ventilator-associated pneumonia is currently a clinical diagnosis made with a new or progressive lung infiltrate on imaging that coincides with clinical signs and symptoms of infection (i.e. leukocytosis, purulent secretions, and fever) as well as a positive pathogen from a respiratory sample (Kollef, 2018). Pneumonia is considered a VAP when it occurs more than 48-72 hours post endotracheal intubation. With the presence of 
radiologic infiltrates and two clinical criteria, the sensitivity of diagnosing VAP is $69 \%$ and the specificity is 75\% (Amanullah, 2015).

Healthcare providers rely upon radiographic, clinical, and laboratory indicators to diagnose VAP and initiate empiric antibiotics. Some of these have been combined into clinical diagnostic models, the most popular of which is the Clinical Pulmonary Infection Score (CPIS). This tool was developed to facilitate the diagnosis of VAP based on points assigned for each of the following signs and symptoms of pneumonia: tracheal secretions, temperature, white blood cell (WBC) count, oxygenation, chest radiograph, and tracheal aspirate culture. A score of $>6$ indicates a VAP is more likely.

A systematic review and meta-analysis by Fernando et al., 2020 sought to characterize and compare the accuracy of physical examination, chest radiography, endotracheal aspirate (ETA), bronchoscopic sampling cultures, and CPIS $>6$ to diagnose VAP. Researchers included 25 studies totaling 1639 patients. Inclusion criteria included: English-language articles through 2019, retrospective and prospective observational studies, RCTs, adult intensive care unit (ICU) patients $\geq 16$ years, and invasive mechanical ventilation $\geq 48$ hours. Additionally, the studies must have evaluated one or more of the following characteristics: fever (defined as body temperature $\geq 38$ degrees Celsius), purulent secretions, leukocytosis (any threshold), chest radiography, gram stain and/or culture from the lungs, or CPIS for diagnosis of VAP. Histopathological analysis from lung biopsy and bronchoalveolar lavage (BAL) were the primary and secondary reference standards, respectively. The two researchers independently extracted data and assessed study quality. 
Fernando et al. (2020) found that none of the clinical diagnostic methods used to diagnose VAP were very accurate. The pooled sensitivity and specificity of physical examination findings for VAP were poor: fever $(66.4 \%$ [95\% CI: 40.7-85.0], 53.9\% [95\% CI 34.5-72.2]) and purulent secretions (77.0\% [95\% CI 64.7-85.9], 39.0\% [95\% CI 25.8-54.0]). An infiltrate on chest radiography had a sensitivity of $88.9 \%$ (95\% CI 73.9-95.8) and specificity of 26.1\% (95\% CI 15.1-41.4). ETA had a sensitivity of $75.7 \%$ (95\% CI 51.5-90.1) and specificity of 67.9\% (95\% CI 40.5-86.8). Protected specimen brush bronchoscopy (PSB) had a sensitivity of 61.4\% [95\% CI 43.7-76.5] and specificity of $76.5 \%$ [95\% CI 64.2-85.6]; while BAL had a sensitivity of 71.1\% [95\% CI 49.9-85.9] and specificity of $79.6 \%$ [95\% CI $66.2-85.9]$. CPIS $>6$ had a sensitivity of $73.8 \%(95 \%$ CI 50.6-88.5) and specificity of $66.4 \%$ (95\% CI 43.9-83.3). The findings were consistent when using either reference standard.

The presence of infiltrate on chest radiography had the highest sensitivity of $88.9 \%$ but had poor specificity. The CPIS was deemed inaccurate by researchers regardless of the reference standard used. This meta-analysis suggests that the methods clinicians routinely use to diagnose VAP and initiate antibiotics in the ICU are neither sensitive nor specific.

The study has some limitations; it does not include the sensitivity and specificity of histopathology from lung biopsy and this was the reference standard utilized suggesting it is most accurate. They did state it was impractical for routine diagnosis, and that results may be influenced by the area of the lung that is biopsied. The study used published data so not all details of subjects included may have been known as well as if 
patients were on antibiotics prior to bronchoscopic sampling, both of which may confound the results.

\section{Consequences of VAP}

Ventilator-associated pneumonia is correlated with increases in mortality, length of stay, and exponential increases in health care costs. A patient with VAP remains in the ICU 4 to 19 days longer than patients who were intubated and did not acquire a VAP. This longer stay is associated with higher costs. The cost of care for a patient with VAP is approximately $\$ 40,000$ to $\$ 57,000$ higher than the cost for a patient on mechanical ventilation without VAP (Sedwick et al., 2012). The mortality rate for VAP ranges from 27-76\% (Amanullah, 2015).

\section{VAP Bundles}

The 100,000 Lives Campaign was a nationwide initiative launched by the Institute for Healthcare Improvement (IHI) in 2006 with a goal to reduce morbidity and mortality in health care in the United States. The campaign focused on six key areas for improvement including: initiating rapid response teams; acute myocardial infarction interventions; preventing adverse drug reactions; preventing central line infections; preventing surgical site infections; and preventing VAP (IHI, n.d.).

The IHI recommends VAP bundles, which are evidenced-based interventions, to improve patient outcomes. The VAP bundle originally included: elevation of the head of bed between 30 and 45 degrees, daily sedation interruptions, daily assessment of readiness to extubate, stress ulcer prophylaxis, and deep vein thrombosis prophylaxis. In the spring of 2010, after new clinical trials were examined, oral care with chlorhexidine $0.12 \%$ was added to the bundle. 
Recent evidence has challenged the VAP bundle and added further up to date recommendations on interventions. "Strategies to Prevent Ventilator-Associated Pneumonia in Acute Care Hospitals: 2014 Update" was published to update the 2008 guidelines to include the new recommendations of the use of subglottic secretion drainage ports for patients likely to require intubation $>48$ hours and only changing the ventilator circuit as needed rather than on a fixed schedule. The subglottic suction drains potential pathogens that pool above the ETT. The humidified gas in the ventilator circuit is at increased risk for contamination with frequent manipulation and would have direct entry through the ETT into the lungs. The new guidelines also do not recommend the use of stress ulcer prophylaxis as it did not have an impact on VAP rates (Klompas, Branson, Eichenwald, et al., 2014). The Intensive Care Society (ICS) and the National Institute for Health and Care Excellence (NICE) recently withdrew its recommendation for the use of oral chlorhexidine in non-cardiac surgery patients in 2016 after a new meta-analysis suggested its association with an increase in mortality (Hellyer et al., 2016). The exact mechanism resulting in higher mortality rates remains unclear, but it may be that some patients aspirate chlorhexidine and develop acute respiratory distress syndrome (ARDS) (Price et al., 2014).

Although many medical experts believe that the campaign has been a success, the IHI has not been able to accurately calculate and quantify the data (IHI, n.d.). A systematic review by Lawrence and Fulbrook (2011) examined the impact of VAP bundles on the incidence of VAP. Inclusion criteria included English language experimental studies between 2004-2009, clinical outcomes measured, and studies that included head of the bed minimum of 30 degrees, daily sedation holiday, gastric ulcer 
prevention, and DVT prophylaxis. Ten studies were included in the review. Three of the studies had chlorhexidine mouth care as a bundle component. The studies included were observational with no control group because the researchers deemed it unethical to not implement the IHI's recommendation for the bundle. Therefore, the researchers could not definitively conclude a causal relationship between the bundle implementation and incidence of VAP; however, there was a positive association.

\section{Chlorhexidine and Oral Care}

Oral $\mathrm{CHG}$ is a prescribed antiseptic that reduces microbial colonization in the oral cavity. It covers a broad spectrum of microorganisms including gram-positive bacteria, gram-negative bacteria, and yeast. A $0.12 \%$ concentration is currently the only oral formulation approved by the Food and Drug Administration (FDA) for use in the United States (Grap et al., 2017). This germicidal rinse is typically used to treat gum disease such as gingivitis and periodontitis in adults. It has been adopted into oral care protocols up to twice daily for mechanically ventilated patients to decrease the pathogen load in oral plaque and the risk of VAP.

The technique of applying CHG during oral care is done by rinsing the mouth with a CHG solution using a sponge or toothbrush followed by oral suction; generally, a suction catheter kit that has a toothbrush or sponge is used. Some manufacturers sell commercially packaged "24-hour systems" which include all-inclusive kits with individually packaged products to use every two to four hours for mouth care. The kits may include mouth moisturizer for every two to four hours and chlorhexidine solution for twice daily oral care $(\mathrm{Q} \bullet$ CareOral Cleansing \& Suctioning Systems, 2018). Many 
hospitals are utilizing these kits; however, there are no universal protocols for continuity between hospitals on exact mouth care procedures and products used.

A prospective, randomized, double-blind, placebo-controlled clinical trial by Ćabov et al. (2010) included a total of 60 intubated patients in a surgical ICU in Croatia assessed whether oral CHG mouth care impacted dental plaque, colonization of the oral cavity, and nosocomial infections. The control group received standard oral care, which consisted of rinsing the mouth with bicarbonate isotonic solution and gentle oropharyngeal sterile suctioning followed by the application of a placebo gel. The experimental group received the same standard care with the addition of a $0.2 \%$ chlorhexidine gel rubbed on the teeth by a gloved finger of a nurse three times daily. Dental status, plaque samples, nasal and tracheal aspirates, and urine samples were obtained 24 hours after admission and then every three days until discharge. Dental status was assessed using the caries-absent-occluded (CAO) dental index which is calculated as the sum of decayed, missing, and filled teeth and ranges from 0 (normal dental status) to 28 (all teeth absent or decayed). The study found that $63 \%$ of patients had preexisting colonized dental plaque and oral mucosa with multiple aerobic organisms on admission. Moreover, they found a positive correlation between colonized dental plaque and the development of numerous nosocomial infections such as bacteremia, UTI, or VAP. The rate of these nosocomial infections was four times lower in the group receiving the chlorhexidine oral care. The most frequently acquired nosocomial infection was pneumonia, with a statistically higher rate of occurrence in the placebo group. More specifically, the number of cases of pneumonia was significantly higher in the placebo group (6/30) than the chlorhexidine group $(1 / 30)(p=0.039)$ (Ćabov et al., 2010). The 
number of patients being admitted colonized with pathogens that cause VAP paired with the positive correlation of chlorhexidine reducing infection rates, supports the theory that chlorhexidine oral care prior to intubation may impact and potentially reduce VAP rates.

The study had some notable limitations. The sample size was small, having only 60 patients, which decreases the power of the study's results. The study also did not compare the differences in infection rates between the patients that came in with colonization versus those that did not. Patients were first randomized into a group by computer generation then swabbed for colonization on admission after being assigned a group. However, the researchers stated there was no statistical differences in bacterial colonization of dental plaque $(P=0.21)$ or buccal mucosa $(P=0.42)$ between the groups on day 0 .

\section{CHG and the Prevention of VAP in Mechanically Ventilated Patients}

Saliva acts as a lubricant to the oral cavity and provides antibacterial and buffering properties in healthy patients. Mechanically ventilated patients may lack saliva related to side effects from the multiple medications they are receiving and prolonged mouth opening related to the ETT (Hua et al., 2016). Regularly scheduled oral care is intended to mimic the function of the saliva by moistening the mouth as well as removing debris and plaque (Hua et al., 2016). Using an antiseptic such as CHG, may further reduce the bacterial burden or delay a subsequent increase in bacterial burden (Hua et al., 2016). Decreasing the bacterial burden from the oral cavity would reduce the opportunity of bacteria being aspirated into the respiratory tract and causing a VAP plaque (Hua et al., 2016). 
A systematic review by Hua et al. (2016) analyzed 38 randomized controls trials comparing four main groups of interventions (CHG mouth rinse vs. placebo, toothbrushing vs. no toothbrushing, powered toothbrush vs. oral care with manual toothbrush, oral care with other solutions) in the oral hygiene care of critically ill patients receiving mechanical ventilation for at least 48 hours in intensive care units. The 18 RCTs that compared $\mathrm{CHG}$ versus placebo used concentrations $0.12 \%, 0.2 \%, 1 \%$, and $2 \%$. The study found the use of chlorhexidine reduced the risk of VAP compared to placebo from $24 \%$ to $18 \%(\mathrm{P}=0.004)$. There was no evidence that use of $\mathrm{CHG}$ was associated with a difference in mortality, duration of mechanical ventilation or duration of ICU stay.

There were some limitations in this systematic review including the potential bias in the variation and subjective nature of criteria used for VAP diagnosis per each study. This makes it difficult to compare VAP results when different diagnostic tools were used to define VAP. Also, the specific details of what was involved in the oral hygiene care intervention were poorly described in some of the studies.

Klompas, Speck, Howell, et al. (2014) conducted a systematic review and metaanalysis of 16 RCTs examining the use of CHG versus placebo on the incidence of VAP. Researchers sought to reappraise the evidence after noting bias in previous systematic reviews. Previous reviews included studies with a majority of cardiac surgery patients that were primarily extubated within 24 hours and that little distinction was made between open-label versus double-blind investigations leading to bias in favor of $\mathrm{CHG}$ use. Due to the lack of gold standard for the diagnosis of VAP the researchers chose to compare duration of mechanical ventilation, length of stay, and mortality as more objective patient-centered outcomes. Inclusion criterion was RCTs evaluating daily oral 
care with $\mathrm{CHG}$ (any preparation) versus a placebo in adult patients receiving mechanical ventilation. Data bases were searched without date restrictions and previously published meta-analyses and the reference lists of all suggestive articles were reviewed for inclusion. Cardiac surgery studies accounted for $51 \%$ of patients and non-cardiac surgery investigations included $49 \%$ of patients in this review.

The results indicated there were fewer lower respiratory tract infections in cardiac surgery patients receiving chlorhexidine (relative risk (RR), 0.56; 95\% confidence interval (CI), 0.41-0.77) but no significant difference in VAP in noncardiac surgery patients (RR, 0.88; 95\% CI, 0.66-1.16). There was no significant difference in mean duration of mechanical ventilation or intensive care length of stay in either groups. There was a nonsignificant result of increased mortality with chlorhexidine use among noncardiac surgery studies. Limitations included the pulmonary outcomes in the cardiac surgery studies were specified as "nosocomial pneumonia," "upper respiratory tract infections," "lower respiratory tract infections," or "total respiratory tract infections" (Klompas, Speck, Howell, et al. 2014), but in all non-cardiac surgery studies the outcomes were defined as VAP. No further definitions were given as to what criteria were used to diagnose these.

Deschepper et. al. (2018) conducted a retrospective, observational cohort study including 82,274 patients hospitalized in various settings in Belgium with the objective of assessing the effect of CHG oral care on mortality. Oral care with $15 \mathrm{~mL} 0.05 \%$ or $0.12 \%$ CHG was given twice daily on general wards and three times daily to ICU patients. A proxy measure for CHG exposure was defined as low $\leq 300 \mathrm{mg}$ or high $>300 \mathrm{mg}$, respectively. Independent patients were given instructions to swish and spit and 
dependent patients had oral swabbing provided by nurses. This two-year study included patients 16 years or more with adjustment for risk of mortality and severity of illness based on the All Patient Refined-Diagnosis Related Groups (APR-DRG). Patients without APR-DRG risk of mortality were excluded as well as childbirth related admissions.

A total of 14\% of patients hospitalized and discharged between 1 January 2012 and 31 December 2014 that met inclusion criteria received CHG oral care during their hospitalization, either in a solution of $0.05 \%(n=1175)$ or $0.12 \%(n=9963)$. The study found no association between $\mathrm{CHG}$ oral care and increased mortality in postoperative cardiothoracic and vascular surgery patients or patients receiving mechanical ventilation. In cardiothoracic and vascular surgery patients the relationship between $\mathrm{CHG}$ oral care and mortality did not reach statistical significance ( $\mathrm{CHG}$ exposure $\leq 300 \mathrm{mg}$ odds ratio (OR) $0.96 ; 95 \%$ CI $0.60-1.55 ; \mathrm{P}=0.874, \mathrm{CHG}$ exposure $>300 \mathrm{mg}$ OR $1.43 ; 95 \% \mathrm{CI}$ 0.88-2.32; $\mathrm{P}=0.146) . \mathrm{CHG}$ oral care was associated with increased risk of death in patients who were not admitted to the ICU and those that did not receive mechanical ventilation. Overall, the patient's with better prognosis on risk assessment for mortality was associated with a greater chance for adverse effects related to $\mathrm{CHG}$ oral care.

The study has several limitations including its observational design which is prone to bias. Also, it is unclear why there were two different doses $(0.05 \%$ and $0.12 \%)$ of $\mathrm{CHG}$, why one was indicated over the other, and why only $14 \%$ of patients included in the study received $\mathrm{CHG}$ oral care during their hospitalization. This is a small percentage of their sample size and is the purpose of the study. Perhaps more strict inclusion criteria were required to yield a higher percentage. The lack of a tangible pathogenic mechanism 
leading to increased risk of mortality leaves the data difficult to interpret. The study proposes micro-aspiration of CHG leading to ARDS or anaphylactic reactions as potential links to increased mortality but states further research is indicated with these outcome criteria.

Varying evidence supports the use of chlorhexidine in select populations and it is being utilized in ICUs throughout the United States, but little research has been done to study when chlorhexidine should be initiated. Given that there is some evidence that CHG use decreases VAP rates and that intubation is a risk for infection, it could be hypothesized that the use of oral chlorhexidine prior to intubation would decrease VAP rates.

\section{Chlorhexidine Prior to Intubation and VAP Prevention}

As previously discussed, the process of intubation is a risk factor for VAP as the ETT passes through the microbe rich oropharynx and down into the lungs. In most other invasive clinical procedures where a tube is inserted, decontamination procedures are done at the insertion site to reduce the risk of colonization or infection. For example, prior to a urinary catheter insertion the meatus is scrubbed with an antiseptic.

Endotracheal intubation usually proceeds without any preparation of the mouth other than the removal of dentures and potentially suctioning of oral secretions. The use of oral chlorhexidine prior to intubation could potentially eliminate the risk of introducing microbes from the oral cavity into the lungs during the intubation procedure (Munro et al., 2015).

Nicolosi et al. (2014) conducted a quasi-experimental study to test this hypothesis. The study took place in a large hospital in Argentina and included patients 
undergoing cardiothoracic surgery. The control and experimental group each included 123 patients. The control group received the hospital's standard preoperative protocol of mupirocin antibiotic nasally for three days prior to surgery, administration of a thirdgeneration cephalosporin 30 minutes before and after surgery, and continuation of the patient's normal oral routine prior to admission. The experimental group received the same treatment with the addition of $0.12 \% \mathrm{CHG}$ every 12 hours for three days preoperatively with education on proper tooth brushing techniques by a dentist. The measurable outcome was the development of VAP. The group that received oral decontamination preoperatively with chlorhexidine had a VAP rate of $2.7 \%$ while the control group had a rate of $8.7 \%$ demonstrating the risk of developing VAP after surgery was more than 3 times greater in patients who did not receive oral decontamination with chlorhexidine. Study limitations include its small sample size and its quasi-experimental design.

A similar prospective intervention study by Bergan et al. (2013) tested the same hypothesis including 226 patients undergoing cardiothoracic surgery at a federal public hospital in Brazil. Patients received education from a dentist on proper tooth brushing techniques and were instructed to rinse their mouth and gargle with CHG $0.12 \%$ twice a day for 2 minutes and just prior to the operating room. Postoperatively, the nurses performed the toothbrushing and $\mathrm{CHG}$ oral care. The measurable outcome was diagnosis of VAP. All patients received two grams of cefazolin 30 minutes before cardiac surgery as standard preoperative prophylaxis. Prior to the implementation of the $\mathrm{CHG}$, the VAP rate was 32 per 1,000 (3.2) ventilator-days; the rate declined to 10 per 1,000 (1) ventilator-days within one year of the start of the new protocol. The hospital had a $69 \%$ 
reduction in the incidence of VAP by 12 months. This is significant since the study also found the presence of pneumonia increased the chances of death by 11 times, $\mathrm{P}<0.0001$. Mortality in patients with pneumonia was 6/19 (33.3\%) versus 9/208 (4.32\%) in those without pneumonia. Limitations include small sample size and being a single center study in the setting of a developing country. The study does speculate that cardiac surgery patients at their institution have lower postoperative pneumonia rates related to their regular referrals for dental care preoperatively to prevent endocarditis.

There are limited randomized control trials investigating the use of oral chlorhexidine prior to intubation and the impact on the incidence of VAP. Four published studies meet inclusion criteria of this systematic review. 


\section{Theoretical Framework}

Louis Pasteur proposed the germ theory in 1858 theorizing that specific organisms are capable of causing infectious diseases. This simple cause and effect theory has been critical to the development of modern medical care and its impact has helped to drastically decrease the number of deaths from infection (Mcewen \& Wills, 2011). Pasteur's theory is predominantly utilized in disease prevention and epidemiological studies. The theory seeks to identify, understand, and manage infectious diseases leading to the development of ways to prevent and treat disease.

This systematic review utilizes the principles of Pasteur's germ theory. During the literature review, the problem of VAP was identified and explored. Causative mechanisms were further investigated with intubation and biofilms identified as leading factors. Methods to prevent VAP were explored specifically focusing on chlorhexidine mouth care prior to intubation. 


\section{Methods}

A systematic review was conducted to determine if the use of oral care with chlorhexidine prior to intubation impacts the incidence of ventilator-associated pneumonia. The Preferred Reporting Items for Systematic reviews and Meta-Analyses (PRISMA) was used to guide the selection process of articles and the Critical Appraisal Skills Programme (CASP) was used to critically appraise the randomized control trials selected for this systematic review. The ethical considerations for this systematic review are that PRISMA, as well as the inclusion and exclusion criteria, were strictly followed.

Using the PRISMA checklist (Appendix A) and the flow diagram (Appendix B), a comprehensive literature search for RCTs was performed using the databases CINHAL, Google Scholar, and Medscape and combining the key terms: ventilator-associated pneumonia; chlorhexidine; oral care; and prior to intubation. The inclusion criteria included randomized control trials, age greater than 18 years, and receiving oral chlorhexidine prior to being intubated. The study had to compare the use of chlorhexidine mouth care prior to intubation versus not using chlorhexidine prior to intubation and the incidence of VAP had to be the measurable outcome. Only articles published in English were reviewed. Exclusion criteria were randomized control trials that did not use chlorhexidine prior to intubation, participants less than 18 years old, non-English language articles, studies that were not randomized control trials, and studies that did not have VAP as the measurable outcome. Literature was searched initially from 2006 to 2020 and then with no date restriction using the above-mentioned inclusion and exclusion criteria related to the limited number of RCTs available on this topic. 
PRISMA consists of a 27-item checklist (Appendix A) and a four-phase flow diagram (Appendix B) that dictates the steps of the evaluation of each study and in turn allows for presentation of the information in a precise and consistent manner. The checklist includes the major sections of a systematic review and what is to be included in each section. These sections include the major categories of title, abstract, introduction, methods, results, and funding (Moher et al., 2009). There are also several subcategories within each section. The PRISMA checklist was utilized to ensure data extracted from each of the included randomized control trials was complete and consistent.

The four-phase flow diagram (Appendix B), including identification, screening, eligibility, and inclusion, was used to select the articles appraised for the systematic review (Moher et al., 2009). Identification involves identifying records through databases and other sources. Screening involves refining the search to only pertinent studies related to the specific research question at hand and eliminating any duplicates that occur. The eligibility phase uses inclusion and exclusion criteria to omit any studies that do not meet criteria and includes an explanation of why. Lastly, the inclusion phase is the final number of studies that will be used in the systematic review. Using this four-phase process, studies were identified, screened for duplicates, and assessed for eligibility, which resulted in a select number of studies to be used in this systematic review.

Once the randomized control trials were selected, each article was analyzed and pertinent data was presented in an organized table (Appendix C1-4) allowing for comparison of the studies' purposes, designs, sites and samples, methods, results, and limitations. Each randomized control trial was then critically appraised using the CASP checklist for RCTs to determine the studies' scientific integrity (Appendix D1-4). 
The CASP is part of the Oxford Centre for Triple Value Healthcare and strives to systematically assess the trustworthiness, relevance, and results of published papers. The CASP checklist for randomized control trials is an 11-question standardized checklist to methodically determine the quality, validity, and integrity of a study (CASP, 2018).

Lastly, a cross study analysis (Appendix E1-4) was performed to compare the placebo used in each study, the CHG dose selected, and the effect on incidence of VAP. The similarities and differences between the studies were compared. 


\section{Results}

\section{Search Results}

The search terms yielded 236 results; 62 duplicates were eliminated leaving 174 remaining for review. The abstracts were then reviewed to determine if they met inclusion and exclusion criteria; 16 articles remained. The full texts of the remaining articles were read and assessed for the inclusion/exclusion criteria, leaving a total of 4 articles that were used in this systematic review. Pertinent data from each article was organized into data a table (Appendix C). Next, each study was summarized as follows and the studies were critically appraised using the CASP checklist (Appendix D).

\section{Study Characteristics}

A randomized control trial by Munro et al. (2015) (Appendix C1) evaluated the benefit of adding a preintubation CHG dose to the hospital's standard postintubation CHG to reduce the risk of VAP. Prior to intubation, study personnel swabbed the oral cavity with $5 \mathrm{~mL}$ of a $0.12 \%$ CHG. Postintubation, the same dose and concentration of CHG was administered by the responsible nurse on a twice daily schedule until extubation. A secondary aim was to test the effect of a preintubation oral application of CHG on early endotracheal tube (ETT) colonization. The RCT included 314 subjects from two large Southern urban teaching hospitals in the United States. Immediately prior to intubation, subjects were recruited from multiple clinical areas, including critical care units, emergency departments, preoperative areas, procedural areas, and medical surgical units during rapid response or code calls. The CHG group was 58\% male with a mean age of 58.1 years and a mean Acute Physiology and Chronic Health Evaluation (APACHE) score of 69.1 . The control group consisted of $62 \%$ males with a mean age of 
58.2 years and a mean APACHE score of 65.1. Patients with a clinical diagnosis of pneumonia at the time of intubation were excluded.

Subjects were randomly assigned to the intervention group that received oral application of $5 \mathrm{~mL} 0.12 \% \mathrm{CHG}$ by oral swab or the control group that received no preintubation intervention. All subjects received $\mathrm{CHG}$ twice a day after intubation as standard of care. The Clinical Pulmonary Infection Score (CPIS) was used to evaluate the risk of VAP with a VAP threshold score of $>6$. Any score $>6$ signified an increased risk for VAP. Researchers chose the CPIS to evaluate the risk of early-onset VAP because it permitted serial prospective evaluation of VAP risk without substantially increasing risks to human subjects. A swab was taken of the distal ETT after extubation to assess the secondary aim of ET colonization.

The results of this study (Appendix E1) demonstrated no statistically significant improvement in CPIS scores from the CHG group over the control group. The mean CPIS scores from both groups remained below the VAP threshold of 6 signifying a VAP was not likely. Regarding the study's secondary aim of ETT colonization occurrence, the majority of ETTs in both study groups were not colonized at the time of extubation ( $81.4 \%$ in the $\mathrm{CHG}$ group and $82.5 \%$ in the control group). There was no statistically significant difference in ETT colonization between the groups $(\mathrm{P}=0.8656)$.

Critical analysis of the Munro et al. (2015) study using the CASP checklist (Appendix D-1) revealed both groups were statistically similar. Although the sample size was small, a priori power analysis was used to determine the sample size required to detect a difference in CPIS of 1 between the two groups. The clinical providers were blinded to study group assignment, as well as the clinical laboratory personnel who 
performed microbial analyses and the coinvestigator who evaluated the chest x-rays. This study had several limitations. Nine subjects in the $\mathrm{CHG}$ group did not receive the intervention and the study does not explain why. Furthermore, there were four subjects listed as "other" that did not remain in the intervention group and eight that did not remain in the control group without rationale as to why. The study reported most subjects were extubated prior to the full 5-day intervention period leading to unavoidable attrition over the course of the study. There was no mention of a standard mouth care swabbing technique or training to ensure continuity and it was being performed by hospital nurses not study personnel. The possibility of data entry error exists due to the possibility that CHG administration was recorded but not actually performed. The CPIS score used as a diagnostic tool for VAP in the study only had a sensitivity of $73.8 \%$ and specificity of $66.4 \%$ (Fernando et al., 2020). Lastly, it is not made clear how randomization was achieved or what additional inclusion criteria was used besides prior to intubation without an existing diagnosis of pneumonia.

Houston et al. (2002) tested the effectiveness of $0.12 \%$ CHG oral rinse compared to the standard control of phenolic mixture (Listerine) in decreasing microbial colonization of the respiratory tract and hospital-acquired pneumonia in patients undergoing open heart surgery. A total of 561 patients undergoing aortocoronary bypass or valve surgery requiring cardiopulmonary bypass were randomized to an experimental $(n=270)$ or a control $(n=291)$ group. The $C H G$ group was $73 \%$ male, and the Listerine group was $79 \%$ male. Patients were excluded from the study if they died during surgery, were pregnant, or had a documented or patient reported preoperative respiratory infection. Patients were randomized by medical record numbers. Preoperatively, both 
groups received $15 \mathrm{~mL}$ of their respective oral rinse to swish and spit and postoperatively received the same by mouth swab twice daily until extubation, tracheostomy, death, or diagnosis of pneumonia. Both groups received preoperative and perioperative prophylactic antibiotics as part of the routine cardiac surgery protocol. Sputum samples were collected every 48 hours until extubation. VAP was diagnosed using criteria established by the Centers for Disease Control and Prevention.

Results of this study (Appendix E-2) revealed that VAP rates did not differ significantly ( $4 / 270$ vs. $9 / 291 ; \mathrm{P}=0.21)$ in the $\mathrm{CHG}$ group compared to the Listerine group. The study also found that only patients intubated for more than 24 hours developed pneumonia $(0 / 486$ vs. $13 / 75 ; \mathrm{P}=0.01)$. The pneumonia rate was reduced by $58 \%(4 / 19$ vs. $9 / 18 ; \mathrm{P}=0.06)$ overall in patients treated with $\mathrm{CHG}$ who were intubated for more than 24 hours and had sputum cultures that showed positive microbial growth. In patients at highest risk for pneumonia (intubated $>24$ hours, with sputum cultures showing the most growth), the rate was $71 \%$ lower in the $\mathrm{CHG}$ group than in the Listerine group ( $2 / 10$ vs. $7 / 10 ; \mathrm{P}=.02)$.

Critical analysis of the Houston et al. (2015) study using the CASP checklist (Appendix D-2) showed the two groups did not differ significantly in characteristics. None of the patients extubated within hours of surgery developed pneumonia. Most patients included in this study were extubated within hours of surgery, therefore, a limitation may be the relatively small sample size. However, the sample size of 600 was projected based on the hospital's historical rate of VAP and was deemed sufficient to detect a 0.20 effect size with $99 \%$ power. Perhaps the biggest limitation of the study is that the researchers did not disclose whether the participants or providers were blinded. 
Age ranges of participants were not included. The study does not state how many doses of oral rinse patients received in total preoperatively. There also could be error in selfreporting of the preoperative doses that patients did independently at home. Some doses may have been skipped and not reported. The study refers to attrition resulting from death and tracheostomy. However, it is not disclosed how many patients were properly accounted for at the conclusion of the study.

DeRiso et al. (1996) examined whether twice daily preoperative use of $0.12 \%$ CHG oral rinse reduced hospital-acquired infection rates in patients undergoing open heart surgery in a prospective, randomized, double-blind, and placebo-controlled study. Of the 353 patients who were included, 173 patients were randomized to the CHG group and 180 to the placebo group. The CHG group was $69 \%$ male with the mean age of 64.1 years and the control group was $68 \%$ male with the mean age of 63.5 years. The chemical make-up of the base solution of both the intervention and placebo oral rinses was similar; the placebo had no antimicrobial properties. Each group received their respective oral rinse twice daily preoperatively with an unspecified number of doses and postoperatively twice daily until discharge from the ICU or death. Prophylactic antibiotics and intravenous ranitidine were given as standard postoperative care. Exclusion criteria were intraoperative death, preoperative infection or intubation, pregnancy, heart and lung transplant recipients, and known hypersensitivity to CHG. The patients who failed early extubation received tracheal aspirate culture at 48 hours and then every two days until discharge from the ICU or death. This study also used the CDC's diagnostic infection criteria for VAP. Outcomes measured were overall rates of nosocomial infections, upper and lower respiratory tract infections, urinary tract infections, fungemias, central line 
infection rates, wound infections, blood infections, other infections, nonprophylactic IV antibiotic use, length of stay (LOS) in the hospital, duration of intubation, need for reintubation, and in-hospital mortality.

Study results pertinent to this review (Appendix E-3) demonstrated an overall decrease in all hospital-acquired infection rates in the $\mathrm{CHG}$ treated patients by $65 \%$ (P $<0.01$ ). Total respiratory tract infections were $69 \%$ less common in the $\mathrm{CHG}$ treated group $(\mathrm{P}<0.05)$ and the use of nonprophylactic IV antibiotics was lowered by $43 \%$ $(\mathrm{P}<0.05)$. Although they found no statistical differences between the two groups regarding average duration of mechanical ventilation, reintubation rate, or length of stay in the hospital, there was a reduction in mortality in the $\mathrm{CHG}$ group versus control group ( $1.16 \%$ vs. $5.56 \%$ respectively).

Critical appraisal (Appendix D-3) of the DeRiso et al. (1996) study using CASP revealed it was unclear whether all patients that entered the study were accounted for at the end of the study. Researchers also did not state why they chose the sample size they selected; however, the sample that was selected did not statistically differ in characteristics. The trial did clearly address the focus issue and the randomized doubleblind placebo-controlled design gives the study further validity.

Lin et al. (2015) investigated the effect of preoperative $0.2 \%$ CHG on postoperative VAP rates. Patients that met inclusion criteria were selected prior to cardiac surgery at a medical university hospital in China. Inclusion criteria were consciousness; age $>18$ years; ability to independently gargle in the oropharynx; and requiring orotracheal intubation and mechanical ventilation. The exclusion criteria were pneumonia before intubation; history of previous heart surgery and intubation; or severe brain, liver, 
or kidney disease. Of the 94 patients that met the inclusion criteria, 47 were randomized to the CHG group and 47 to the control group. All patients were blinded to their grouping.

The day prior to surgery the CHG group gargled with $50 \mathrm{~mL} 0.2 \% \mathrm{CHG} 30$ minutes after all meals and 5 minutes after brushing teeth at bedtime. CHG was gargled for 30 seconds and was repeated three times at one-minute intervals while the control group gargled with normal saline adhering to the same schedule. Postoperatively, as part of standard care while on mechanical ventilation, both groups had oral rinses with $50 \mathrm{~mL}$ of $0.2 \% \mathrm{CHG}$, four times a day. After extubation, they were each required to gargle once with $50 \mathrm{~mL}$ of $0.2 \% \mathrm{CHG}$ then once after each meal for three days. The oral care of all patients was performed by the same two trained healthcare professionals who were blinded to the patients grouping. The outcome of VAP was diagnosed using the simplified Clinical Pulmonary Infection Score (CPIS) and was assessed on days 1, 3, 5, and 7 after intubation with a threshold of $\geq 6$. Patients with CPIS $\geq 6$ and $<6$ were classified as those with and without VAP, respectively.

Results of the study (Appendix E-4) revealed that preoperative CHG mouthwash reduced the incidence of postoperative VAP significantly; VAP occurred in $8.5 \%$ of the chlorhexidine group and $23.4 \%$ in the control group $(\mathrm{P}=0.049)$. CPIS scores were not different between the two groups on postoperative day one; however, they were significantly lower in the $\mathrm{CHG}$ group on the third $(\mathrm{P}=0.024)$ and fifth $(\mathrm{P}=0.005)$ day when compared to the controls.

Critical analysis of the Lin et al. (2015) study using the CASP checklist (Appendix D-4) revealed the study clearly addressed the focus of this review and met all 
criteria other than the small sample size of only 47 in each group. To achieve a power of $80 \%$ with a risk ratio of 0.36 over 90 patients would have been required in each group. The ideal power of $80 \%$ means the study would have a high chance of detecting a difference between the two groups. Since the study fell short of this goal without explanation, caution should be used when drawing conclusions as to whether there was a true difference between the two groups. The researchers had used a prior study to estimate the group sizing, which was 98 in each group, so they still fell short based on their initial needs assessment. This known small sample size is a limitation of the study. Additionally, the preoperative rinse was to be used the day before surgery after meals and before bed. This may lead to some patients receiving a different number of doses based on how many meals were eaten that day. The total $\mathrm{mL}$ of preoperative $\mathrm{CHG}$ and saline was not disclosed. Furthermore, self-reporting the correct use of four times a day preoperative $\mathrm{CHG}$ oral rinse may have led to error related to inaccurate reporting from patients. The study design is unclear with researchers stating 1:1 randomization by computer generator followed by statements that the treating physician assigned the groups the day before surgery. Lastly, the study does not make clear if the two trained and blinded nurses performing oral care, data collection, and diagnosis of VAP were from the researchers' team or the hospital's. 


\section{Cross Analysis}

A cross study analysis table (Appendix E) was created to compare the RCTs used for this systematic review. The table includes which placebo was utilized, the CHG dose and frequency of administration and the effect on incidence of VAP.

A different placebo and $\mathrm{CHG}$ dose were used in each of the four RCTs. Munro et al. (2015) were the only researchers to investigate noncardiac surgery patients. They included patients from multiple clinical areas of the hospital including those prior to emergent intubations. The intervention group received $5 \mathrm{~mL} 0.12 \% \mathrm{CHG}$ prior to intubation while the control group received no $\mathrm{CHG}$ prior to intubation. The intervention group received $5 \mathrm{~mL} 0.12 \% \mathrm{CHG}$ by swab to the oral cavity administered by study personnel prior to intubation while the control group received none. After intubation both groups received $5 \mathrm{~mL} 0.12 \% \mathrm{CHG}$ administered by the responsible nurse twice daily until extubation. Houston et al. (2002) used $15 \mathrm{~mL}$ of Listerine brand phenolic mouth rinse as the placebo. Each group received $15 \mathrm{~mL}$ of either the Listerine mixture or $0.12 \%$ CHG preoperatively (30 sec swish \& spit) and twice daily postoperatively (30 sec swab) for 10 days postoperatively or until extubation, tracheostomy, death, or diagnosis of pneumonia. DeRiso et al. (1996) used a placebo with similar chemical makeup without CHG or antimicrobial properties that had identical packing. Either the placebo or the $0.12 \%$ CHG was given twice daily preoperatively, however, the study failed to disclose for how many days. Postoperatively $15 \mathrm{~mL}$ of either solution as an oropharyngeal rinse or rigorously applied to the buccal, pharyngeal, gingival, tongue, and tooth surfaces for 30 seconds twice daily until discharge from the ICU or death. Lastly, Lin et al., 2015 used $0.9 \%$ saline solution as a placebo in the control group but did not specify the amount. The 
day prior to surgery, patients gargled three times with $50 \mathrm{~mL} 0.2 \% \mathrm{CHG}$ or the saline placebo 30 minutes after all meals and 5 minutes after brushing teeth at bedtime. Either solution was gargled for 30 seconds and was repeated three times at one-minute intervals. Once intubated both groups had oral rinse with $50 \mathrm{~mL}$ of $0.2 \% \mathrm{CHG}$ four times a day.

Three of the four RCTs, Houston et al. (2002), DeRiso et al. (1996), and Lin et al. (2015), showed an improvement in VAP rates with the use of preintubation CHG. Only one RCT, the Munro et al. (2015) study, showed no benefit. There was no statistically significant improvement in the CPISs from the CHG group over the control group and both groups CPS scores remained less than the VAP threshold of 6 . In regard to the study's secondary aim of evaluating preintubations impact on ETT colonization, both groups were $<20 \%$ colonized with no significant difference $(\mathrm{P}=0.8656)$.

There were some variances in the amount of total risk reduction among the other three studies that found a reduction in VAP with the use of preintubation CHG. Houston et al. (2002) found the overall rate of nosocomial pneumonia was reduced by $52 \%(4 / 270$ vs $9 / 291 ; \mathrm{P}=.21$ ) in the CHG-treated patients. DeRiso et al. (1996) found VAP 69\% less common in the CHG-treated group compared to the placebo group (5/173 vs $17 / 180 ; p<$ 0.05). Lin et al. (2015) found an absolute risk reduction of VAP with the CHG group of $14.9 \%(23.4 \% / 8.5 \%)$ 


\section{Discussion}

The previously discussed differences in the dosages and application techniques may have influenced these varying results as well as many other factors that will be discussed in the summary and conclusions section.

Ventilator-associated pneumonia is a major concern in hospitals that is correlated with increases in mortality, length of stay, and exponential increases in health care costs (Sedwick et al., 2012). In response to this, the IHI developed VAP bundles in 2006, which are evidenced-based interventions to improve patient outcomes. The inclusion of oral care with chlorhexidine $0.12 \%$ was made in the spring of 2010 after new clinical trials suggested an improvement in VAP rates. There have been multiple changes to the bundle over the years related to updated recommendations following new clinical trial. The ICS and NICE withdrew its recommendation for the use of oral chlorhexidine in non-cardiac surgery patients in 2016 after a new meta-analysis suggested its association with an increase in mortality (Hellyer et al., 2016). There is limited research exploring the proper time to initiate chlorhexidine. The purpose of this paper is to determine if the use of oral care with chlorhexidine prior to intubation impacts the incidence of ventilator-associated pneumonia.

A comprehensive literature search for RCTs was performed using the databases CINHAL, Google Scholar, and Medscape. The PRISMA 27-item checklist and four-phase diagram (Moher et al., 2009) were utilized in the search process to ensure a thorough selection of studies. This search strategy resulted in four RCTs meeting inclusion criteria for this systematic review. Pertinent data from these studies were then organized into a data collection table (Appendices C1-4) allowing for comparison of the studies' purposes, designs, sites and samples, methods, results, and limitations. The CASP checklist for RCTs 
was used for critically appraisal to determine the scientific integrity of each of the four studies (Appendix D1-4). Lastly, a cross study analysis (Appendix E1-4) was performed to compare the placebo used in each study, the CHG dose selected, and the effects of the intervention variables on the incidence of VAP.

Three of the four RCTs, Houston et al. (2002), DeRiso et al. (1996), and Lin et al., (2015), showed an improvement in VAP rates with the use of preintubation CHG. Only one RCT, the Munro et al., 2015 study, showed no benefit. This was the only study that included non-cardiac surgery patients. Researchers did not perform any analysis on the varying types of patients and the incidence on VAP. It is recommended that a secondary analysis be done specific to cardiac surgery patients to see the impact of CHG application on the incidence of VAP in this population. The Society of Thoracic Surgeons (STS) promotes the practice of extubating patients within 6 hours after cardiac surgery as a quality of care benchmark (Goeddel, Hollander \& Evans, 2018) while other patient populations requiring mechanical ventilation tend to remain intubated longer. The inclusion of other patient populations in the Monroe et al. (2015) study may have negatively impacted results.

One of the significant challenges in diagnosing VAP is that there is no recognized diagnostic gold standard or definition (Kollef, 2018) and the definition has evolved over time. VAP is currently a clinical diagnosis therefore subjective to some extent varying from provider to provider based on his or her interpretation. Fernando et al. (2020) found that none of the clinical diagnostic methods used to diagnose VAP were very accurate. Some of the radiographic, clinical, and laboratory indicators were combined into clinical diagnostic models, the most popular of which is the Clinical Pulmonary Infection Score (CPIS). This scale was also deemed unreliable by Fernando et al. (2020) with a sensitivity 
of $73.8 \%$ (95\% CI 50.6-88.5) and specificity of $66.4 \%$ (95\% CI 43.9-83.3). There were differences in the four studies in the criteria used to diagnose VAP. The CPIS score was utilized in the Lin et al. (2015) and Munro et al. (2015) while the CDC criteria was used to diagnose VAP in the older RCTs DeRiso et al. (1996) and Houstan et. al (2002). Since none of the clinical diagnostic methods used to diagnose VAP were reliable perhaps more concrete primary outcomes such as mortality, duration of intubation, and antibiotic utilization should be used.

\section{Limitations}

There were several limitations in this systematic review. Only four studies met the inclusion and exclusion criteria which may affect generalizability. Also, all the RCTs were relatively small with each including between 94-561 participants. Practice differences related to ever changing standards of care plays a large factor in difficulties comparing the RCTs. Some of the trials date back prior to the initiation of the bundles; DeRiso et al. was published in 1996 and Houstan et. al in 2002, both well before the initiation of the IHI bundle in 2006. Therefore only Lin et al., (2015) and Munro et al., (2015) included all updates to the bundles to include elevation of the head of the bed to $30^{\circ}$ to $45^{\circ}$; prophylaxis for peptic ulcer disease; prophylaxis for deep-vein thrombosis; daily interruption of sedation (sedation holiday); daily assessment of readiness for extubation; the use of subglottic secretion drainage ports for patients likely to require intubation $>48$ hours and only changing the ventilator circuit as needed rather than on a fixed schedule as well as daily oral care with chlorhexidine. Therefore, the bundle itself is a cofounder in the newer studies since it may be responsible for some of the positive effects and CHG alone cannot be held solely accountable. 
Another limitation with comparing studies is the differing concentrations of $\mathrm{CHG}$ used. A $0.12 \%$ concentration is currently the only oral formulation approved by the Food and Drug Administration (FDA) for use in the United States (Oral Care for Acutely and Critically Ill Patients, 2017). Lin et al. (2015) was the only study to use a strength other than $0.12 \%$; researchers used $0.2 \%$ as the study was done in China where this concentration is available. All other studies were performed in the United States.

Lastly, there is no worldwide standardized mouth care protocol. Each study had a different method, duration, length of time and process for the administration of either the placebo or the CHG. This may have further influenced the ability to fairly compare the results. 


\section{Summary and Conclusions}

The results of this systematic review demonstrate the use of $\mathrm{CHG}$ prior to intubation was effective in reducing the VAP rates in post-cardiac surgery patients in three of the four studies included in this review. These findings are not generalizable, however, related to the lack of large, randomized control trials including both cardiac and noncardiac patients. It remains unclear as to most effective dosing, frequency, and application procedure of CHG. The majority of patients in the studies were intubated for less than one week, however, some studies did not disclose an exact number of days. There is no evidence demonstrating a definitive time frame of $\mathrm{CHG}$ use related to length of intubation post cardiac surgery. Also, now that oral CHG is not being utilized in non-cardiac ICU patients, further studies of its use prior to intubation could be more accurate as they will not be receiving the $\mathrm{CHG}$ after intubation. More research is needed to determine effective dosing, frequency, and application procedures of $\mathrm{CHG}$ as well as exploring if it is safe to administer CHG prior to intubation in noncardiac surgery patients.

Although there were several limitations in the RCTs and some differences made them difficult to compare, the achievement of the primary aim in this systematic review results in recommendations and implications that can be made for the advanced practice nurse in the clinical setting. 


\section{Recommendations and Implications for Advanced Nursing Practice}

The role of the advanced practice nurse (APN) has evolved to meet the challenge of access to health care across the United States. APNs have become an integral part of healthcare teams in both the inpatient and outpatient setting. APNs utilize evidence-based practice (EBP) methods to provide safe and efficient care to their patients. This systematic review presents evidence-based findings that may guide APNs in making informed decisions in future practice.

Based on this systematic review, it can only be recommended that cardiac surgery patients receive $\mathrm{CHG}$ prior to and after intubation; however, more research needs to be done to determine the effective dosing, frequency, and application procedures as well as exploring if it is safe to administer $\mathrm{CHG}$ prior to intubation in noncardiac surgery patients.

The results of this systematic review demonstrate the use of $\mathrm{CHG}$ prior to intubation was effective in reducing the VAP rates in three of the four studies included in this review; however, the three studies that did show an improvement only included cardiac surgery patients. Munro et al., (2015) was the only study to include non-cardiac surgery patients including emergent intubations and the results yielded no benefit with the use of CHG and VAP. The ICS and the NICE withdrew its recommendation for the use of oral CHG in non-cardiac surgery patients in 2016 after a new meta-analysis suggested its association with an increase in mortality (Hellyer et al., 2016). Now that oral CHG is not being utilized in non-cardiac ICU patients, further studies of its use prior to intubation could be more accurate as they will not be receiving the $\mathrm{CHG}$ after intubation. APNs are in a position to lead research projects and develop new EBP 
standards and implementation in clinical practice. In addition, they can develop safe policies and educate staff on safe practices.

Further research is recommended. The next RCT trials to explore CHG prior to intubation should have larger sample sizes and the controls should be double blind. Utilizing different primary outcomes in these studies such as mortality, duration of intubation, and antibiotic usage may be more effective in quantifying VAP occurrences than the previously used ineffective CPIS scores. These outcomes may be more sensitive regarding the impact of VAP since there remains no gold standard for diagnosing it.

The lack of a standardized approach to mouth care in the ICU setting was also evident throughout this review. The APN has the ability to work closely with interdisciplinary teams, including dentistry, to create one evidence-based, standard approach to oral care in intubated patients. Creating such a procedure with a stepwise approach would create continuity across ICUs worldwide.

The current healthcare environment focus is on delivering superior patient care for less cost. Low expenditure preventative interventions such as oral care with $\mathrm{CHG}$ could help reduce VAP rates and decrease mortality, length of stay, and costs. Ventilatorassociated pneumonia has a detrimental cost effect on the healthcare system and more research should be executed focused on prevention including trials of CHG application prior to intubation in noncardiac surgery patients. The APN can then use this knowledge to train bedside nurses who provide oral care to ensure it is performed appropriately. As research for VAP prevention advances, the diagnosis for this complex condition will be more universally understood and more interventions put into practice to improve patient outcomes. 


\section{References}

American Thoracic Society; Infectious Diseases Society of America. (2005) Guidelines for the management of adults with hospital-acquired, ventilator-associated, and healthcare-associated pneumonia. American Journal Respiratory Critical Care Medicine, 171, 388-416. https://doi: 10.1164/rccm.200405-644ST

Amanullah, S. (2015, December 31). Ventilator-associated pneumonia overview of nosocomial pneumonias. http://misc.medscape.com/pi/android/medscapeapp/ html/A304836-business.html

Bergan, E. H., Tura, B. R., \& Lamas, C. C. (2013). Impact of improvement in preoperative oral health on nosocomial pneumonia in a group of cardiac surgery patients: A Single arm prospective intervention study. Intensive Care Medicine, 40(1), 23-31. doi: 10.1007/s00134-013-3049-y

Berry, A., Davidson, P., Masters, J., Rolls, K., \& Ollerton, R. (2011). Effects of three approaches to standardized oral hygiene to reduce bacterial colonization and ventilator-associated pneumonia in mechanically ventilated patients: A randomized control trial. International Journal of Nursing Studies, 48(6), 681688. doi: https://10.1016/j.ijnurstu.2010.11.004 (Available at www.ihi.org).

Bonez, P. C., Alves, C. F. D. S., Dalmolin, T. V., Agertt, V. A., Mizdal, C. R., Flores, V. D. C., Campos, M. M. A. D. (2013). Chlorhexidine activity against bacterial biofilms. American Journal of Infection Control, 41(12). doi: 10.1016/j.ajic. 2013.05.002

Ćabov, T., Macan, D., Husedžinović, I., Škrlin-Šubić, J., Bošnjak, D., Šestan-Crnek, S., Golubović, V. (2010). The impact of oral health and $0.2 \%$ chlorhexidine oral gel 
on the prevalence of nosocomial infections in surgical intensive-care patients: A randomized placebo-controlled study. Wiener Klinische Wochenschrift, 122(1314), 397-404. doi: 10.1007/s00508-010-1397-y

Critical Appraisal Skills Programme. (2018). Retrieved from https://casp-uk.net/aboutus/ DeRiso, A. J., 2nd, Ladowski, J. S., Dillon, T. A., Justice, J. W., \& Peterson, A. C. (1996). Chlorhexidine gluconate $0.12 \%$ oral rinse reduces the incidence of total nosocomial respiratory infection and nonprophylactic systemic antibiotic use in patients undergoing heart surgery. Chest, 109(6), 1556-1561. https://doi.org/ 10.1378/chest.109.6.1556

Deschepper, M., Waegeman, W., Eeckloo, K., Vogelaers, D., \& Blot, S. (2018). Effects of chlorhexidine gluconate oral care on hospital mortality: A hospital-wide, observational cohort study. Intensive care medicine, 44(7), 1017-1026. https://doi.org/10.1007/s00134-018-5171-3

Fernando, S.M., Tran, A., Cheng, W. et al. Diagnosis of ventilator-associated pneumonia in critically ill adult patients - a systematic review and meta-analysis. Intensive Care Med 46, 1170-1179 (2020). https://doi.org/10.1007/s00134-020-06036-z

Goeddel, L. A., Hollander, K. N., \& Evans, A. S. (2018). Early extubation after cardiac surgery: A better predictor of outcome than metric of quality? Journal of Cardiothoracic and Vascular Anesthesia, 32(2), 745-747. https://doi.org/10.1053/ j.jvca.2017.12.037

Hellyer, T. P., Ewan, V., Wilson, P., \& Simpson, A. J. (2016). The Intensive Care Society recommended bundle of interventions for the prevention of ventilator- 
associated pneumonia. Journal of the Intensive Care Society, 17(3), 238-243. https://doi.org/10.1177/1751143716644461

Houston, S., Hougland, P., Anderson, J. J., LaRocco, M., Kennedy, V., \& Gentry, L. O. (2002). Effectiveness of $0.12 \%$ chlorhexidine gluconate oral rinse in reducing prevalence of nosocomial pneumonia in patients undergoing heart surgery. American Journal of Critical Care: An Official Publication, American Association of Critical-Care Nurses, 11(6), 567-570.

Hua F, Xie H, Worthington HV, Furness S, Zhang Q, Li C. (2016). Oral hygiene care for critically ill patients to prevent ventilator-associated pneumonia. Cochrane Database of Systematic Reviews 2016, Issue 10. Art. No.: CD008367. DOI: 10.1002/14651858.CD008367.pub3

Klompas, M., Branson, R., Eichenwald, E., Greene, L., Howell, M., Lee, G., Magill S., Maragakis L., Priebe G., Speck K., Yokoe D., Berenholtz S., (2014). Strategies to prevent ventilator-associated pneumonia in acute care hospitals: 2014 Update. Infection Control and Hospital Epidemiology, 35(8), 915-936. https://doi: $10.1086 / 677144$

Klompas, M., Speck, K., Howell, M. D., Greene, L. R., \& Berenholtz, S. M. (2014). Reappraisal of routine oral care with chlorhexidine gluconate for patients receiving mechanical ventilation. JAMA Internal Medicine, 174(5), 751. doi: 10.1001/jamainternmed.2014.359

Kollef, M. H. (2018). Clinical presentation and diagnostic evaluation of ventilatorassociated pneumonia. https://www.uptodate.com/contents/clinical-presentationand-diagnostic-evaluation-of-ventilator-associated-pneumonia 
Lawrence, P., \& Fulbrook, P. (2011). The ventilator care bundle and its impact on ventilator-associated pneumonia: A review of the evidence. Nursing in Critical Care, 16(5), 222-234. https://doi.org/10.1111/j.1478-5153.2010.00430.x

Lin, Y. J., Xu, L., Huang, X. Z., Jiang, F., Li, S. L., Lin, F., Ye, Q. Y., Chen, M. L., \& Lin, J. L. (2015). Reduced occurrence of ventilator-associated pneumonia after cardiac surgery using preoperative $0.2 \%$ chlorhexidine oral rinse: Results from a single-centre single-blinded randomized trial. The Journal of Hospital Infection, 91(4), 362-366. https://doi.org/10.1016/j.jhin.2015.08.018

Mcewen, M., \& Wills, E. M. (2011). Theoretical basis for nursing (3rd ed.). Wolters Kluwer Health.

Moher D, Liberati A, Tetzlaff J, Altman DG, The PRISMA Group (2009) Preferred Reporting Items for Systematic Reviews and Meta-Analyses: The PRISMA Statement. PLoS Med 6(7): e1000097. doi: 10.1371/journal.pmed.1000097

Munro, C. L., Grap, M. J., Sessler, C. N., Elswick, R. K., Mangar, D., Karlnoski-Everall, R., \& Cairns, P. (2015). Preintubation application of oral chlorhexidine does not provide additional benefit in prevention of early-onset ventilator-associated pneumonia. Chest, 147(2), 328-334. doi: 10.1378/chest.14-0692

Nicolosi, L. N., Rubio, M. D. C., Martinez, C. D., Gonzalez, N. N., \& Cruz, M. E. (2014). Effect of oral hygiene and $0.12 \%$ chlorhexidine gluconate oral rinse in preventing ventilator-associated pneumonia after cardiovascular surgery. Respiratory Care, 59(4), 504-509. doi: 10.4187/respcare.02666

Grap, M.J., Martin, B., Munro, C., (2017). Oral care for acutely and critically ill patients. Critical Care Nurse, 37(3), 19-21. doi: 10.4037/ccn2017179 
Pasteur, Louis. (2016, May 20). Retrieved April 19, 2020, from https://www. famousscientists.org/louis-pasteur/

Price, R., MacLennan, G., Glen, J., \& SuDDICU Collaboration. (2014). Selective digestive or oropharyngeal decontamination and topical oropharyngeal chlorhexidine for prevention of death in general intensive care: systematic review and network meta-analysis. BMJ (Clinical research ed.), 348, g2197. https://doi. org/10.1136/bmj.g2197

Q•Care ${ }^{\circledR}$ Oral Cleansing \& Suctioning Systems. (2018). Retrieved October 31, 2020, from https://sageproducts.com/oral-hygiene-for-ventilated-patients/

Safdar, N., Crnich, C. J., \& Maki, D. G. (2005). The pathogenesis of ventilator-associated pneumonia: Its relevance to developing effective strategies for prevention. Respiratory Care, 50(6), 725-741. Retrieved from http://rc.rcjournal.com/content/ respcare/50/6/725.full.pdf

Sedwick, M., Lance-Smith, M., Reeder, S., \& Nardi, J. (2012). Using evidence-based practice to prevent ventilator-associated pneumonia. Critical Care Nurse 32(4), 41-51. 
Appendix A

\section{Check List for Preferred Reporting Items for Systematic Reviews and Meta-}

\section{Analyses (Moher et al., 2009)}

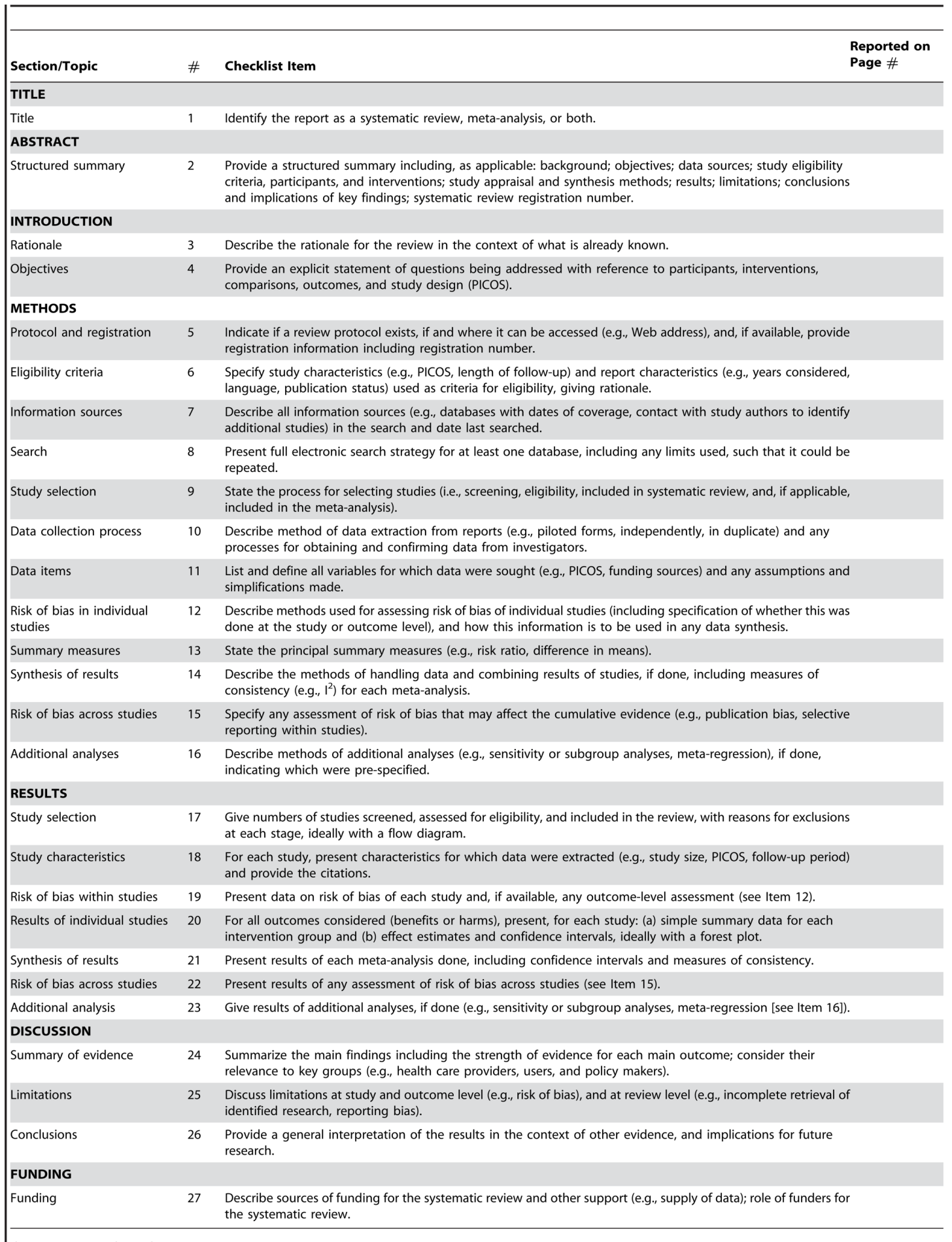

doi:10.1371/journal.pmed.1000097.t001 


\section{Appendix B}

Flow diagram for preferred reporting items for systematic reviews and metaanalyses (Moher et al., 2009)

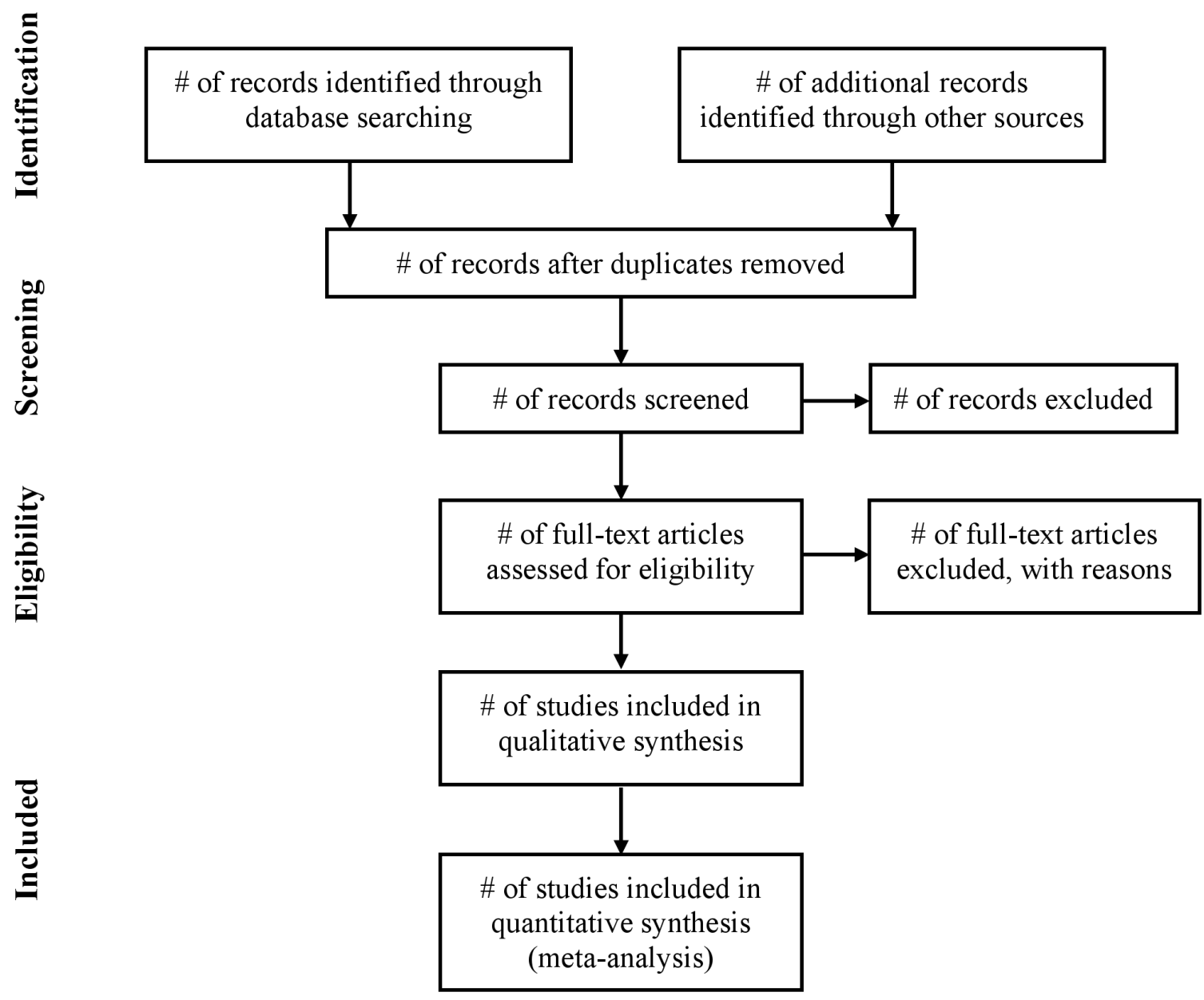




\section{Appendix C-1}

\section{Descriptive Data Tables}

Munro, C. L., Grap, M. J., Sessler, C. N., Elswick, R. K., Mangar, D., Karlnoski-Everall, R., \& Cairns, P. (2015). Preintubation Application of Oral Chlorhexidine Does Not Provide Additional Benefit in Prevention of Early-Onset Ventilator-Associated Pneumonia. Chest, 147(2), 328-334. doi:

10.1378/chest.14-0692

\begin{tabular}{|c|c|c|c|c|c|}
\hline Purpose & Design & Site/Sample & Methods & Results & Limitations \\
\hline $\begin{array}{l}\text { Primary aim to test the effect } \\
\text { of preintubation } 0.12 \% \text { CHG } \\
\text { in reducing VAP risk. } \\
\text { Secondary aim to test the } \\
\text { effect of preintubation } 0.12 \% \\
\text { CHG on early ET } \\
\text { colonization. }\end{array}$ & $\begin{array}{l}\text { Clinical } \\
\text { randomized } \\
\text { control trial }\end{array}$ & $\begin{array}{l}314 \text { subjects from multiple clinical } \\
\text { areas (just prior to intubation, } \\
\text { including critical care units, EDs, } \\
\text { preoperative areas, procedural areas, } \\
\text { and medical surgical } \\
\text { units during rapid response or code } \\
\text { calls) were recruited by meeting } \\
\text { inclusion criteria and being just prior } \\
\text { to intubation at } 2 \text { large urban teaching } \\
\text { hospitals in Virginia. Intervention } \\
\text { group with CHG prior to intubation }= \\
\text { 157, control group = } 157 . \\
\text { IRB approved a waiver of prospective } \\
\text { consent but required written } \\
\text { documentation of consent (including } \\
\text { information about voluntary } \\
\text { withdrawal) from the subjects, } \\
\text { legally authorized representatives at } \\
\text { the earliest opportunity following } \\
\text { study enrollment. } \\
\text { Mean age (SD): intervention group = } \\
\text { 59.5 (11.5), control group = 56.4 } \\
\text { (16.5) } \\
\text { Gender: male/female in intervention } \\
\text { group = 55/45, control group= 60/40 } \\
\text { Mean APACHE score (SD): } \\
\text { intervention group = } 81.2(25.2) \\
\text { control group = 73.3 } \\
(26.3) \\
\text { Exclusion criteria: Clinical diagnosis } \\
\text { of pneumonia at time of intubation. }\end{array}$ & $\begin{array}{l}\text { Subjects randomly assigned to } \\
\text { intervention group who received } \\
\text { oral application of } 5 \text { mL CHG } \\
0.12 \% \text { solution before intubation } \\
\text { or to a control group who } \\
\text { received no CHG before } \\
\text { intubation. } \\
\text { All subjects received CHG twice } \\
\text { a day after intubation. } \\
\text { Preop: oral application of } 5 \mathrm{~mL} \\
\text { 0.12\% CHG solution by swab to } \\
\text { the oral cavity administered by } \\
\text { study personnel } \\
\text { Postop: } 5 \text { mL } 0.12 \% \text { CHG } \\
\text { administered by the responsible } \\
\text { nurse on a twice daily schedule } \\
\text { until extubation. } \\
\text { Subjects remained in the study } \\
\text { for a max of } 6 \text { days. If extubated } \\
\text { prior to } 6 \text { days, the } \\
\text { participation ended on the day of } \\
\text { extubation. } \\
\text { Groups were compared using a } \\
\text { repeated-measures model with } \\
\text { Clinical Pulmonary Infection } \\
\text { Score (CPIS) as the response } \\
\text { measure. ETTs were cultured at } \\
\text { extubation. } \\
\text { Clinical providers, laboratory } \\
\text { personnel, and radiologists were } \\
\text { all blinded to study groups. }\end{array}$ & $\begin{array}{l}\text { Application of a preintubation } \\
\text { dose of CHG did not provide } \\
\text { benefit. } \\
\text { The P values from comparing } \\
\text { each group's change from } \\
\text { baseline with study days } 2,3 \text {, } \\
4, \text { and } 5 \text { were } 0.4217,0.9930 \text {, } \\
0.1484 \text {, and } 0.1763, \\
\text { respectively. } \\
\text { ETT colonization at } \\
\text { extubation was } 20 \% \text { in both } \\
\text { groups; no statistically } \\
\text { significant difference (P = } \\
0.8656) \text {. } \\
\text { Mean CPIS remained below } 6 \\
\text { (VAP threshold score) in both } \\
\text { groups. }\end{array}$ & $\begin{array}{l}\text { Relatively small sample size } \\
\text { but priori power analysis } \\
\text { utilized to determine sample } \\
\text { size required. } \\
\text { May have been variations in } \\
\text { the procedure of swabbing the } \\
\text { oral cavities postintubation } \\
\text { since this was done by staff at } \\
\text { the hospital not the study } \\
\text { personnel. } \\
\text { Most subjects were extubated } \\
\text { prior to the full } 5 \text {-day } \\
\text { intervention period. } \\
\text { No standard noted for the } \\
\text { procedure of swabbing to } \\
\text { ensure continuity. } \\
\text { Medical records were audited } \\
\text { to ensure postintubation } \\
\text { administration of CHG was } \\
\text { given so there may be a } \\
\text { chance it was scanned but not } \\
\text { given. } \\
\text { Does not state how } \\
\text { randomization was achieved } \\
\text { or what inclusion criteria was } \\
\text { besides being prior to } \\
\text { intubation without an existing } \\
\text { diagnosis of pneumonia. }\end{array}$ \\
\hline
\end{tabular}




\section{Appendix C-2}

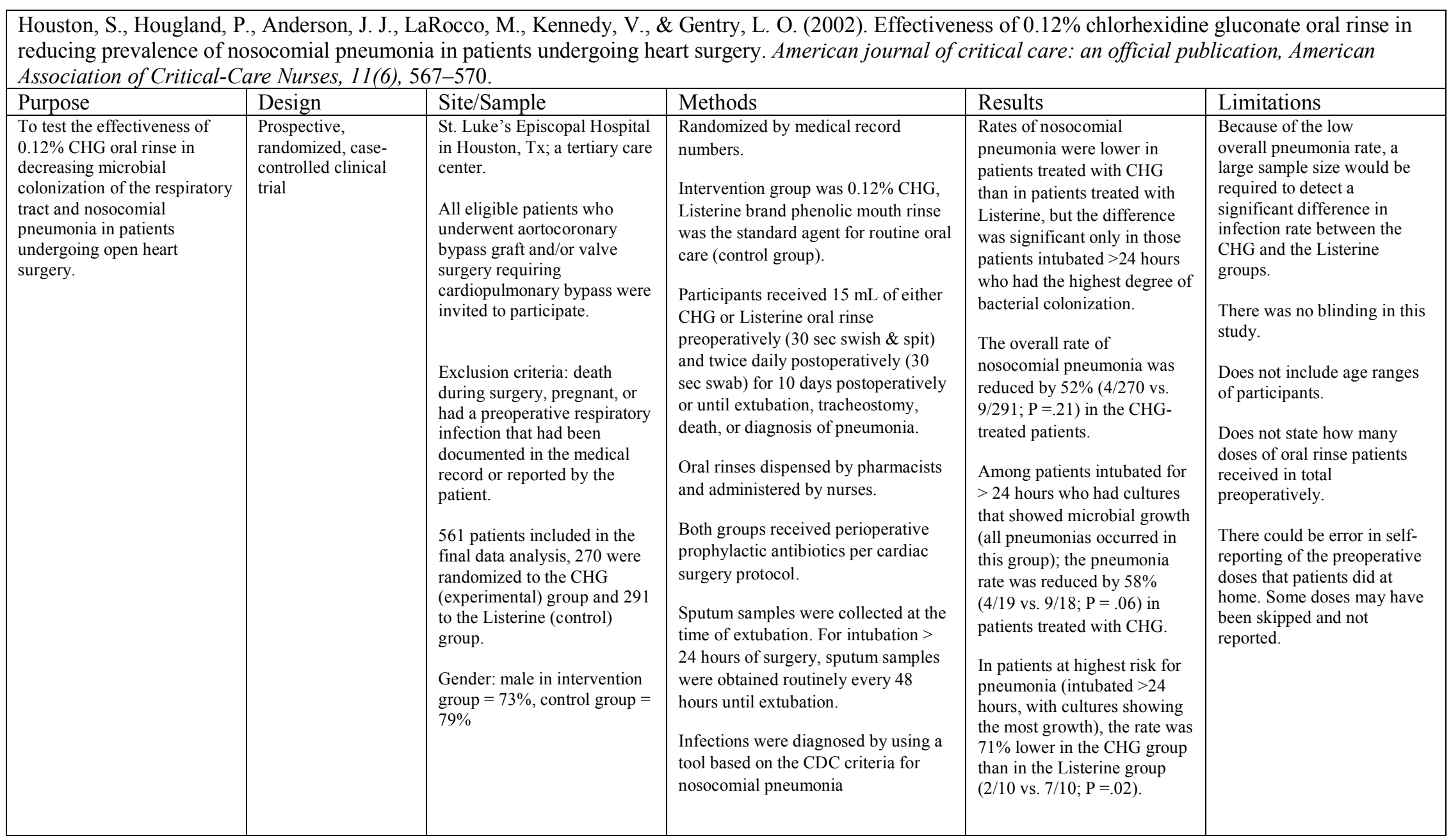




\section{Appendix C-3}

\begin{tabular}{|c|c|c|c|c|c|}
\hline Purpose & Design & Site/Sample & Methods & Results & Limitations \\
\hline $\begin{array}{l}\text { Primary aim was to test the } \\
\text { hypothesis that the } \\
\text { preoperative use of twice- } \\
\text { daily } 0.12 \% \text { CHG oral rinse } \\
\text { can reduce nosocomial } \\
\text { infection rates in patients } \\
\text { undergoing open heart } \\
\text { surgery. } \\
\text { Additional outcome measures } \\
\text { - Overall nosocomial } \\
\text { infection rates } \\
\text { - Upper and lower } \\
\text { respiratory tract infection } \\
\text { rates } \\
\text { - Urinary tract infection rates } \\
\text { - Fungemias } \\
\text { - Line infection rates } \\
\text { - Wound infection rates } \\
\text { - Blood infection rates } \\
\text { - Other infections } \\
\text { - Nonprophylactic IV } \\
\text { antibiotic use } \\
\text { - Length of stay (LOS) in the } \\
\text { hospital } \\
\text { - Duration of intubation } \\
\text { - Need for reintubation } \\
\text { - In-hospital mortality }\end{array}$ & $\begin{array}{l}\text { Prospective, randomized, } \\
\text { double-blind, placebo- } \\
\text { controlled clinical trial }\end{array}$ & $\begin{array}{l}\text { Cardiovascular ICU at } \\
\text { Lutheran Hospital of Indiana, } \\
\text { a tertiary care hospital } \\
353 \text { consecutive patients } \\
\text { undergoing coronary artery } \\
\text { bypass grafting, valve, or } \\
\text { other open-heart surgical } \\
\text { procedures chosen \& } \\
\text { randomized. } \\
\text { Exclusion criteria: } \\
\text { intraoperative death, } \\
\text { preoperative infection or } \\
\text { intubation, pregnancy, heart } \\
\text { and lung transplant recipients, } \\
\text { and known hypersensitivity to } \\
\text { CHG. } \\
\text { Consecutive eligible patients } \\
\text { over a } 10 \text {-month period prior } \\
\text { to cardiac surgery were } \\
\text { invited to participate. } \\
\text { Gender: male/female in } \\
\text { intervention group }=119 / 54, \\
\text { control group }=123 / 57 \\
\text { Mean ages intervention group } \\
=64.1, \text { control group }=63.5 .\end{array}$ & $\begin{array}{l}\text { Participants were randomized } \\
\text { by computer-driven random } \\
\text { number generator into either } \\
\text { the CHG } 0.12 \% \text { or placebo } \\
\text { solutions that were liquids of } \\
\text { comparable color, taste, and } \\
\text { smell were dispensed. Oral } \\
\text { rinse given preoperatively and } \\
\text { twice daily postoperatively } \\
\text { until discharge from the ICU } \\
\text { or death. } \\
\text { Doses were } 0.5 \text { fl oz ( } 15 \mathrm{~mL}) \\
\text { as an oropharyngeal rinse or } \\
\text { rigorously applied to the } \\
\text { buccal, pharyngeal, gingival, } \\
\text { tongue, and tooth surfaces for } \\
30 \text { seconds twice daily. } \\
\text { Both groups received } \\
\text { perioperative prophylactic } \\
\text { antibiotics per cardiac surgery } \\
\text { protocol. } \\
\text { Patients who failed early } \\
\text { extubation (within } 24 \text { hours) } \\
\text { received tracheal aspirate } \\
\text { culture analysis at } 48 \text { hours } \\
\text { and then every } 2 \text { days until } \\
\text { discharged from the ICU or } \\
\text { death. Infections were } \\
\text { diagnosed by CDC criteria for } \\
\text { nosocomial pneumonia. }\end{array}$ & $\begin{array}{l}\text { The overall nosocomial } \\
\text { infection rate was decreased } \\
\text { in the CHG-treated } \\
\text { patients compared to the } \\
\text { placebo group by } 65 \%(8 / 173 \\
\text { vs. } 24 / 180 ; \mathrm{p}<0.01) \\
\text { respectively. } \\
\text { Respiratory tract infections } \\
\text { were } 69 \% \text { less common in the } \\
\text { CHG-treated group compared } \\
\text { to the placebo group }(5 / \\
173 \text { vs. } 17 / 180 ; \mathrm{p}<0.05) \text {. } \\
\text { A reduction in mortality in } \\
\text { the CHG-treated group was } \\
\text { also noted }(1.16 \% \text { vs. } 5.56 \%) \text {. }\end{array}$ & $\begin{array}{l}\text { Does not specify how long } \\
\text { preoperatively patients used } \\
\text { CHG. } \\
\text { There could be error in self- } \\
\text { reporting of the preoperative } \\
\text { doses that patients did at } \\
\text { home. Some doses may have } \\
\text { been skipped and not } \\
\text { reported. }\end{array}$ \\
\hline
\end{tabular}




\section{Appendix C-4}

\begin{tabular}{|c|c|c|c|c|c|}
\hline Purpose & Design & Site/Sample & Methods & Results & Limitations \\
\hline $\begin{array}{l}\text { To investigate the effect of } \\
\text { preoperative } 0.2 \% \text { CHG on } \\
\text { postoperative incidence of } \\
\text { VAP. }\end{array}$ & $\begin{array}{l}\text { Single-center } \\
\text { single-blinded } \\
\text { randomized trial }\end{array}$ & $\begin{array}{l}\text { Patients who met inclusion } \\
\text { and exclusion criteria from } \\
\text { those scheduled for cardiac } \\
\text { surgery between August } \\
2013 \text { and April } 2014 \text { at the } \\
\text { Fujian Medical University } \\
\text { Union Hospital, China. } \\
\text { The inclusion criteria were } \\
\text { conscious; age }>18 \text { years; } \\
\text { able to gargle in the } \\
\text { oropharynx by themselves; } \\
\text { and required orotracheal } \\
\text { intubation and mechanical } \\
\text { ventilation. } \\
\text { The exclusion criteria were } \\
\text { pneumonia before } \\
\text { intubation; history of } \\
\text { previous heart surgery and } \\
\text { intubation; or severe brain, } \\
\text { liver, or kidney disease. } \\
\text { Of the } 94 \text { patients who met } \\
\text { the inclusion criteria, } 47 \\
\text { were randomized to the } \\
\text { CHG group and } 47 \text { to the } \\
\text { control group. }\end{array}$ & $\begin{array}{l}\text { 1:1 Randomization was by a } \\
\text { computer-generated random } \\
\text { number table and sealed } \\
\text { envelopes prepared by a } \\
\text { statistician. The treating } \\
\text { physician assigned the patient to } \\
\text { a group the day before surgery. } \\
\text { All patients were blinded to their } \\
\text { grouping. } \\
\text { In the CHG group, patients } \\
\text { gargled with } 50 \text { mL } 0.2 \% \text { CHG } \\
30 \text { minutes after all meals and } 5 \\
\text { minutes after brushing teeth at } \\
\text { bedtime. CHG was gargled for } \\
30 \text { seconds and was repeated } \\
\text { three times at one-minute } \\
\text { intervals while the control group } \\
\text { gargled with normal saline } \\
\text { adhering to the same schedule. } \\
\text { All oral care and data collection } \\
\text { were done by same two trained } \\
\text { and blinded nurses to avoid bias. } \\
\text { The outcome of VAP was } \\
\text { diagnosed using the simplified } \\
\text { Clinical Pulmonary Infection } \\
\text { Score (CPIS) and was assessed } \\
\text { on days } 1,3,5 \text {, } \\
\text { and } 7 \text { after intubation. A CPIS } \\
\text { score }>6 \text { is suggestive of } \\
\text { pneumonia. }\end{array}$ & 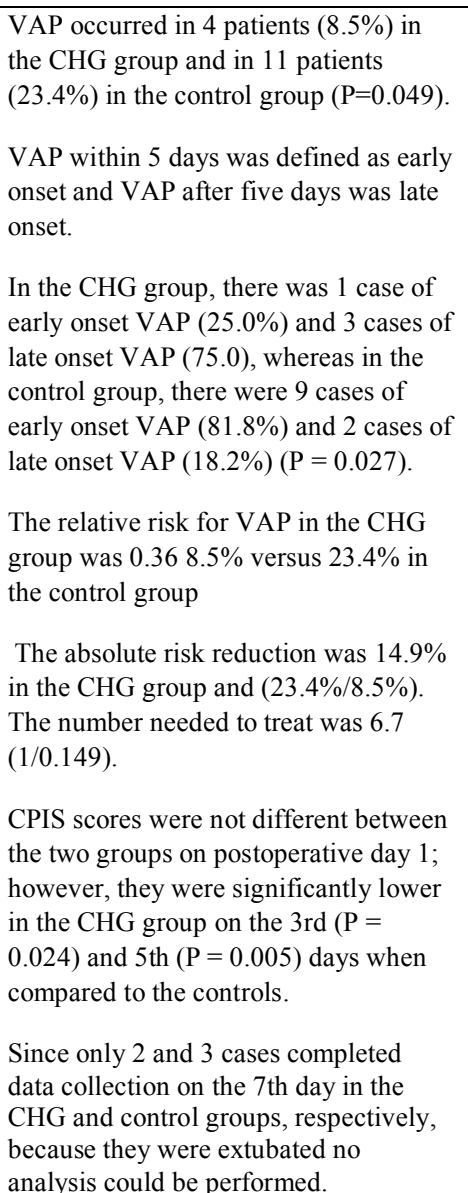 & $\begin{array}{l}\text { The preoperative rinse was used } \\
\text { the day before surgery after } \\
\text { meals and before bed; some } \\
\text { patients may have used different } \\
\text { amounts of doses based on how } \\
\text { many meals eaten that day. } \\
\text { Total mL of preoperative CHG } \\
\text { and saline was not disclosed. } \\
\text { Risk for self-reporting error by } \\
\text { patients about how often they } \\
\text { performed the preoperative rinse } \\
\text { The sample size was small and } \\
\text { to achieve a power of } 80 \% \text { at a } \\
\text { risk ratio of } 0.36 \text { over } 90 \\
\text { patients would have been } \\
\text { required in each arm. } \\
\text { The presence of VAP was only } \\
\text { analyzed for the first seven } \\
\text { postoperative days. } \\
\text { Unclear study design stating } 1: 1 \\
\text { randomization by computer } \\
\text { generator but then states } \\
\text { physician assigned the groups. } \\
\text { Study does not make clear if the } \\
\text { two trained and blinded nurses } \\
\text { performing oral care, data } \\
\text { collection, and diagnosis of } \\
\text { VAP were from their team or } \\
\text { the hospitals. }\end{array}$ \\
\hline
\end{tabular}




\section{Appendix D-1}

\section{CASP Checklist}

Munro, C. L., Grap, M. J., Sessler, C. N., Elswick, R. K., Mangar, D., Karlnoski-Everall, R., \& Cairns, P. (2015). Preintubation Application of Oral Chlorhexidine Does Not Provide Additional Benefit in Prevention of Early-Onset Ventilator-Associated Pneumonia. Chest, 147(2), 328-334. doi: $10.1378 /$ chest.14-0692

\begin{tabular}{|c|c|c|c|c|}
\hline 1 & Did the trial address a clearly focused issue? & Yes & $\begin{array}{l}\text { Can't } \\
\text { tell }\end{array}$ & No \\
\hline 2 & Was the assignment of patients to treatments randomized? & Yes & $\begin{array}{l}\text { Can't } \\
\text { tell }\end{array}$ & No \\
\hline 3 & $\begin{array}{l}\text { Were all the patients who entered the trial properly accounted for at } \\
\text { its conclusion? }\end{array}$ & Yes & $\begin{array}{l}\text { Can't } \\
\text { tell }\end{array}$ & No \\
\hline 4 & $\begin{array}{l}\text { Were patients, health workers and study personnel 'blind' to } \\
\text { treatment? }\end{array}$ & Yes & $\begin{array}{l}\text { Can't } \\
\text { tell }\end{array}$ & No \\
\hline 5 & Were the groups similar at the start of the trial? & Yes & $\begin{array}{l}\text { Can't } \\
\text { tell }\end{array}$ & No \\
\hline 6 & $\begin{array}{l}\text { Aside from the experimental intervention, were the groups treated } \\
\text { equally? }\end{array}$ & Yes & $\begin{array}{l}\text { Can't } \\
\text { tell }\end{array}$ & No \\
\hline 7 & $\begin{array}{l}\text { How large was the treatment effect? ETT colonization at extubation } \\
\text { was, } 20 \% \text { in both groups (no statistically significant difference P } \\
=0.8656 \text { ). }\end{array}$ & Yes & $\begin{array}{l}\text { Can't } \\
\text { tell }\end{array}$ & No \\
\hline 8 & $\begin{array}{l}\text { How precise was the estimate of the treatment effect? A logistic } \\
\text { regression analysis was performed using the binary response } \\
\text { variable of colonization or no colonization and dependent variables } \\
\text { for group, length of intubation, and group-by-length-of-intubation } \\
\text { interaction. The probability of a type } 1 \text { error (alpha) was set to } 0.05 \text {. }\end{array}$ & Yes & $\begin{array}{l}\text { Can't } \\
\text { tell }\end{array}$ & No \\
\hline 9 & $\begin{array}{l}\text { Can the results be applied in your context? (or to the local } \\
\text { population?) }\end{array}$ & Yes & $\begin{array}{l}\text { Can't } \\
\text { tell }\end{array}$ & No \\
\hline 10 & Were all clinically important outcomes considered? & Yes & $\begin{array}{l}\text { Can't } \\
\text { tell }\end{array}$ & No \\
\hline 11 & Are the benefits worth the harms and costs? & Yes & $\begin{array}{l}\text { Can't } \\
\text { tell }\end{array}$ & No \\
\hline
\end{tabular}




\section{Appendix D-2}

\begin{tabular}{|c|c|c|c|c|}
\hline & $\begin{array}{l}\text { n, S., Hougland, P., Anderson, J. J., LaRocco, M., Kennedy, V., \& } \\
\text { veness of } 0.12 \% \text { chlorhexidine gluconate oral rinse in reducing prev } \\
\text { mia in patients undergoing heart surgery. American journal of critic } \\
\text { tion, American Association of Critical-Care Nurses, } 11(6), 567-57\end{array}$ & $\begin{array}{l}\text { try, } \\
\text { are }\end{array}$ & $\begin{array}{l}\text { os }(2 \\
\text { offic } \\
\text { offic }\end{array}$ & \\
\hline 1 & Did the trial address a clearly focused issue? & Yes & $\begin{array}{l}\text { Can't } \\
\text { tell }\end{array}$ & No \\
\hline 2 & Was the assignment of patients to treatments randomized? & Yes & $\begin{array}{l}\text { Can't } \\
\text { tell }\end{array}$ & No \\
\hline 3 & $\begin{array}{l}\text { Were all the patients who entered the trial properly accounted for at } \\
\text { its conclusion? }\end{array}$ & Yes & $\begin{array}{l}\text { Can't } \\
\text { tell }\end{array}$ & No \\
\hline 4 & $\begin{array}{l}\text { Were patients, health workers and study personnel 'blind' to } \\
\text { treatment? }\end{array}$ & Yes & $\begin{array}{l}\text { Can't } \\
\text { tell }\end{array}$ & No \\
\hline 5 & Were the groups similar at the start of the trial? & Yes & $\begin{array}{l}\text { Can't } \\
\text { tell }\end{array}$ & No \\
\hline 6 & $\begin{array}{l}\text { Aside from the experimental intervention, were the groups treated } \\
\text { equally? }\end{array}$ & Yes & $\begin{array}{l}\text { Can't } \\
\text { tell }\end{array}$ & No \\
\hline 7 & $\begin{array}{l}\text { How large was the treatment effect? The overall rate of nosocomial } \\
\text { pneumonia was reduced by } 52 \%(4 / 270 \text { vs. } 9 / 291 ; \mathrm{P}=.21) \text { in the } \\
\text { CHX patients. }\end{array}$ & Yes & $\begin{array}{l}\text { Can't } \\
\text { tell }\end{array}$ & No \\
\hline 8 & $\begin{array}{l}\text { How precise was the estimate of the treatment effect? This sample } \\
\text { size was sufficient to detect a } 0.20 \text { effect size with } 99 \% \text { power. }\end{array}$ & Yes & $\begin{array}{l}\text { Can't } \\
\text { tell }\end{array}$ & No \\
\hline 9 & $\begin{array}{l}\text { Can the results be applied in your context? (or to the local } \\
\text { population?) }\end{array}$ & Yes & $\begin{array}{l}\text { Can't } \\
\text { tell }\end{array}$ & No \\
\hline 10 & Were all clinically important outcomes considered? & Yes & $\begin{array}{l}\text { Can't } \\
\text { tell }\end{array}$ & No \\
\hline 11 & Are the benefits worth the harms and costs? & Yes & $\begin{array}{l}\text { Can't } \\
\text { tell }\end{array}$ & No \\
\hline
\end{tabular}




\section{Appendix D-3}

DeRiso, A. J., 2nd, Ladowski, J. S., Dillon, T. A., Justice, J. W., \& Peterson, A. C. (1996). Chlorhexidine gluconate $0.12 \%$ oral rinse reduces the incidence of total nosocomial respiratory infection and nonprophylactic systemic antibiotic use in patients undergoing heart surgery. Chest, 109(6), 1556-1561. https://doi.org/0.1378/chest.109.6.1556

\begin{tabular}{|c|c|c|c|c|}
\hline 1 & Did the trial address a clearly focused issue? & Yes & $\begin{array}{l}\text { Can't } \\
\text { tell }\end{array}$ & No \\
\hline 2 & Was the assignment of patients to treatments randomized? & Yes & $\begin{array}{l}\text { Can't } \\
\text { tell }\end{array}$ & No \\
\hline 3 & $\begin{array}{l}\text { Were all the patients who entered the trial properly accounted for at } \\
\text { its conclusion? }\end{array}$ & Yes & $\begin{array}{l}\text { Can't } \\
\text { tell }\end{array}$ & No \\
\hline 4 & $\begin{array}{l}\text { Were patients, health workers and study personnel 'blind' to } \\
\text { treatment? }\end{array}$ & Yes & $\begin{array}{l}\text { Can’t } \\
\text { tell }\end{array}$ & No \\
\hline 5 & Were the groups similar at the start of the trial? & Yes & $\begin{array}{l}\text { Can't } \\
\text { tell }\end{array}$ & No \\
\hline 6 & $\begin{array}{l}\text { Aside from the experimental intervention, were the groups treated } \\
\text { equally? }\end{array}$ & Yes & $\begin{array}{l}\text { Can't } \\
\text { tell }\end{array}$ & No \\
\hline 7 & $\begin{array}{l}\text { How large was the treatment effect? } 69 \% \text { reduction in the incidence } \\
\text { of total respiratory tract infections in the CHX-treated group }(17 / 180 \\
\text { vs. } 5 / 173 ; \mathrm{p}<0.05) \text {. A reduction in mortality in the CHX-treated } \\
\text { group was also noted }(1.16 \% \text { vs. } 5.56 \%) \text {. }\end{array}$ & Yes & $\begin{array}{l}\text { Can't } \\
\text { tell }\end{array}$ & No \\
\hline 8 & $\begin{array}{l}\text { How precise was the estimate of the treatment effect? Statistical } \\
\text { analysis was carried out via computer using software (Systat } \\
\text { Statistical). Analysis of variance was used to compare numeric data, } \\
\text { while the } x 2 \text { test with Yates' correction or the Fisher's Exact Test } \\
\text { was used for categorical data depending on the sample size. In all } \\
\text { cases, significance was defined as } p<0.05 \text {. }\end{array}$ & Yes & $\begin{array}{l}\text { Can't } \\
\text { tell }\end{array}$ & No \\
\hline 9 & $\begin{array}{l}\text { Can the results be applied in your context? (or to the local } \\
\text { population?) }\end{array}$ & Yes & $\begin{array}{l}\text { Can't } \\
\text { tell }\end{array}$ & No \\
\hline 10 & Were all clinically important outcomes considered? & Yes & $\begin{array}{l}\text { Can't } \\
\text { tell }\end{array}$ & No \\
\hline 11 & Are the benefits worth the harms and costs? & Yes & $\begin{array}{l}\text { Can't } \\
\text { tell }\end{array}$ & No \\
\hline
\end{tabular}




\section{Appendix D-4}

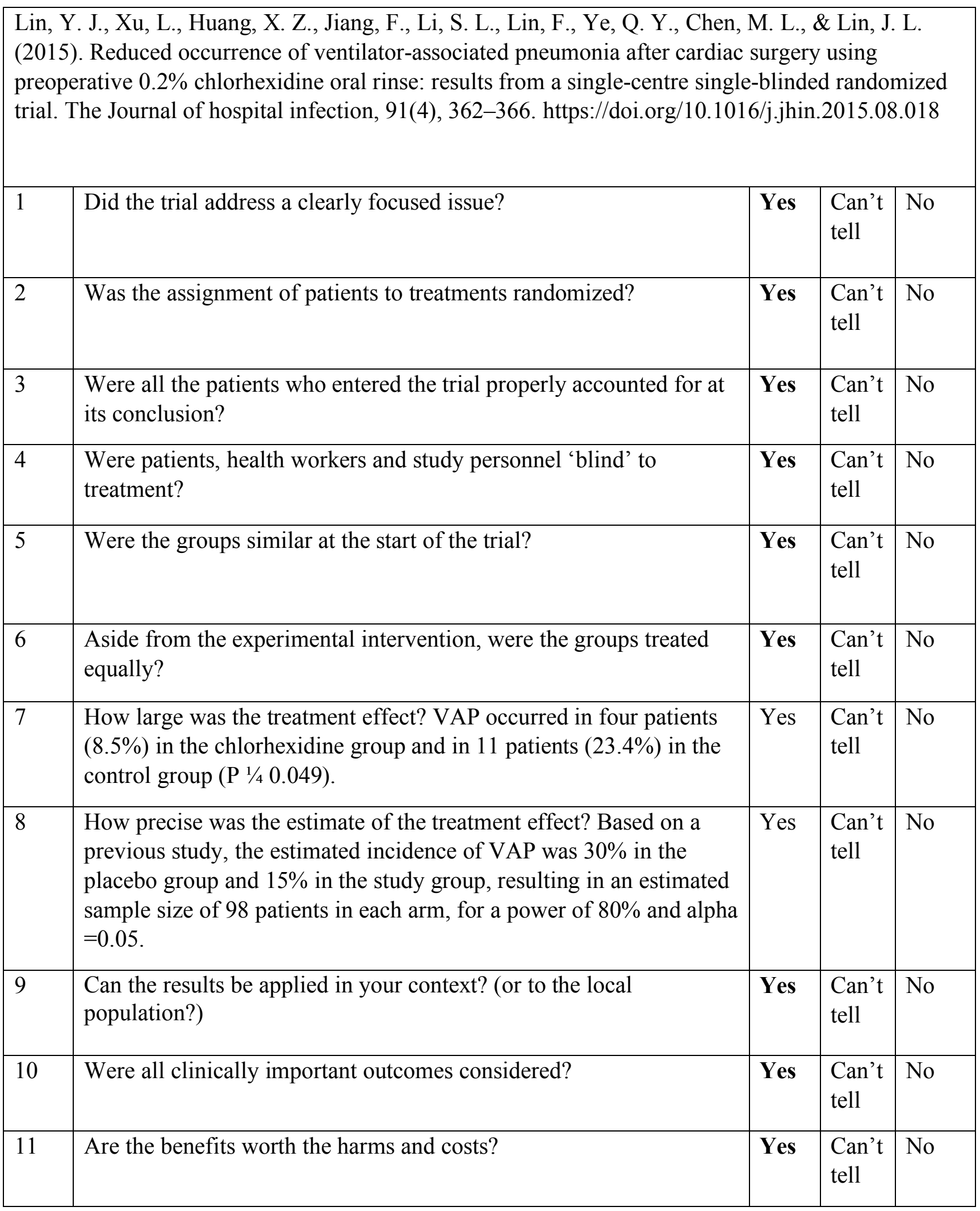


Appendix E

Cross Study Analysis

\begin{tabular}{|c|c|c|c|}
\hline Study/Year & $\begin{array}{l}\text { Identified } \\
\text { Placebo }\end{array}$ & $\begin{array}{l}\text { CHG Dose/ } \\
\text { Frequency }\end{array}$ & $\begin{array}{l}\text { Effect on Incidence of } \\
\text { VAP (Results) }\end{array}$ \\
\hline Munro et al., 2015 & $\begin{array}{l}\text { No preintubation } \\
\text { CHG }\end{array}$ & $\begin{array}{l}\text { Preintubation: } 5 \mathrm{~mL} \\
0.12 \% \text { CHG by swab } \\
\text { to the oral cavity } \\
\text { administered by study } \\
\text { personnel } \\
\text { Postop: } 5 \mathrm{~mL} 0.12 \% \\
\text { CHG administered by } \\
\text { the responsible nurse } \\
\text { twice daily until } \\
\text { extubation }\end{array}$ & $\begin{array}{l}\text { Application of a } \\
\text { preintubation dose of } \\
\text { CHG did not provide } \\
\text { benefit in reducing } \\
\text { incidence of VAP } \\
\text { Mean CPIS }<6 \text { (VAP } \\
\text { threshold score) in both } \\
\text { groups. } \\
\text { Secondary aim of } \\
\text { evaluating preintubations } \\
\text { impact on ETT } \\
\text { colonization: both groups } \\
\text { were }<20 \% \text { colonized } \\
\text { with no significant } \\
\text { difference (P = 0.8656). }\end{array}$ \\
\hline Houston et al., 2002 & $\begin{array}{l}15 \text { mL Listerine } \\
\text { brand phenolic } \\
\text { mouth rinse } \\
\text { (Given on same } \\
\text { schedule as CHG } \\
\text { administration) }\end{array}$ & $\begin{array}{l}15 \mathrm{~mL} 0.12 \% \\
\text { preoperatively ( } 30 \\
\text { second swish \& spit) } \\
\text { and twice daily } \\
\text { postoperatively ( } 30 \\
\text { second swab) for } 10 \\
\text { days postoperatively } \\
\text { or until extubation, } \\
\text { tracheostomy, death, } \\
\text { or diagnosis of } \\
\text { pneumonia. }\end{array}$ & $\begin{array}{l}\text { The overall rate of } \\
\text { nosocomial pneumonia } \\
\text { was reduced by } 52 \% \\
(4 / 270 \text { vs. } 9 / 291 ; \mathrm{P}=.21) \\
\text { in the CHG-treated } \\
\text { patients. } \\
\text { Among patients intubated } \\
\text { for }>24 \text { hours who had } \\
\text { cultures that showed } \\
\text { microbial growth (all } \\
\text { pneumonias occurred in } \\
\text { this group); the } \\
\text { pneumonia rate was } \\
\text { reduced by } 58 \% \text { ( } 4 / 19 \text { vs. } \\
9 / 18 ; \mathrm{P}=.06) \text { in patients } \\
\text { treated with CHG. } \\
\text { In patients at highest risk } \\
\text { for pneumonia (intubated } \\
>24 \text { hours, with cultures } \\
\text { showing the most } \\
\text { growth), the rate was } 71 \% \\
\text { lower in the CHG group } \\
\text { than in the Listerine group } \\
(2 / 10 \text { vs. } 7 / 10 ; \mathrm{P}=.02) .\end{array}$ \\
\hline
\end{tabular}




\begin{tabular}{|c|c|c|c|}
\hline Study/Year & $\begin{array}{l}\text { Identified } \\
\text { Placebo }\end{array}$ & $\begin{array}{l}\text { CHG Dose/ } \\
\text { Frequency }\end{array}$ & $\begin{array}{l}\text { Effect on Incidence of } \\
\text { VAP (Results) }\end{array}$ \\
\hline DeRiso et al., 1996 & $\begin{array}{l}\text { Similar chemical } \\
\text { makeup without } \\
\text { CHG or } \\
\text { antimicrobial } \\
\text { properties. } \\
\text { Identical } \\
\text { packaging. } \\
\text { (Given on same } \\
\text { schedule as CHG } \\
\text { administration) }\end{array}$ & $\begin{array}{l}\text { Twice daily } \\
\text { preoperative } 0.12 \% \\
\text { CHG (unspecified for } \\
\text { how many days } \\
\text { preoperatively). Then } \\
\text { postoperatively } 15 \\
\text { mL } 0.12 \% \text { as an } \\
\text { oropharyngeal rinse } \\
\text { or rigorously applied } \\
\text { to the buccal, } \\
\text { pharyngeal, gingival, } \\
\text { tongue, and tooth } \\
\text { surfaces for } 30 \\
\text { seconds twice daily } \\
\text { until discharge from } \\
\text { the ICU or death. }\end{array}$ & $\begin{array}{l}\text { Respiratory tract } \\
\text { infections } \\
\text { were } 69 \% \text { less common in } \\
\text { the CHG-treated group } \\
\text { compared to the placebo } \\
\text { group (5/173 vs. } 17 / 180 \text {; } \\
\text { p }<0.05) \text {. }\end{array}$ \\
\hline Lin et al., 2015 & $\begin{array}{l}0.9 \% \text { NS } \\
\text { (unspecified } \\
\text { amount) } \\
\text { (Given on same } \\
\text { schedule as CHG } \\
\text { administration) }\end{array}$ & $\begin{array}{l}50 \mathrm{~mL} 0.2 \% \text { CHG } 30 \\
\text { minutes after all } \\
\text { meals and } 5 \text { minutes } \\
\text { after brushing teeth at } \\
\text { bedtime. Either } \\
\text { solution was gargled } \\
\text { for } 30 \text { seconds and } \\
\text { was repeated three } \\
\text { times at one-minute } \\
\text { intervals. Once } \\
\text { intubated both groups } \\
\text { had oral rinse with } 50 \\
\mathrm{~mL} \text { of } 0.2 \% \text { CHG } \\
\text { four times a day. }\end{array}$ & $\begin{array}{l}\text { VAP occurred in } 4 \\
\text { patients }(8.5 \%) \text { in the } \\
\text { CHG group and in } 11 \\
\text { patients }(23.4 \%) \text { in the } \\
\text { control group }(\mathrm{P}=0.049) \text {. } \\
\text { Absolute risk reduction } \\
\text { was } 14.9 \%(23.4 \% / 8.5 \%) \text {. }\end{array}$ \\
\hline
\end{tabular}

